NBER WORKING PAPER SERIES

\title{
THE EFFECTS OF WELFARE AND TAX REFORM: \\ THE MATERIAL WELL-BEING OF SINGLE MOTHERS IN THE 1980s AND 1990s
}

\author{
Bruce D. Meyer \\ James X. Sullivan \\ Working Paper 8298 \\ http://www.nber.org/papers/w8298 \\ NATIONAL BUREAU OF ECONOMIC RESEARCH \\ 1050 Massachusetts Avenue \\ Cambridge, MA 02138 \\ May 2001
}

We would like to thank Greg Duncan, Thomas Gannon-Rowley, Jon Gruber, Thomas Wiseman, the Poverty Fellows at the JCPR and seminar participants at Northwestern University, the National Research Council, the NBER Summer Institute, and the JCPR Conference on Incentive Effects of Tax and Transfer Policies for their comments. We are also indebted to Rebecca Blank and Geoffrey Wallace for the welfare caseload data, and to Geoffrey Paulin, Wolf Weber, and others at the Bureau of Labor Statistics who provided assistance with the expenditure data. The views expressed herein are those of the authors and not necessarily those of the National Bureau of Economic Research.

C 2001 by Bruce D. Meyer and James X. Sullivan. All rights reserved. Short sections of text, not to exceed two paragraphs, may be quoted without explicit permission provided that full credit, including (C) notice, is given to the source. 
The Effects of Welfare and Tax Reform:

The Material Well-Being of Single Mothers in the 1980s and 1990s

Bruce D. Meyer and James X. Sullivan

NBER Working Paper No. 8298

May 2001

JEL No. D12, H31, I30

\begin{abstract}
$\underline{\text { ABSTRACT }}$
The tax and welfare programs that provide income and in-kind benefits to single mothers have changed dramatically in recent years. These changes began as far back as the mid-1980s and culminated with the 1996 welfare law that "ended welfare as we knew it." These tax and welfare changes have sharply increased the employment of single mothers and cut welfare rolls. However, little is know about the effects of these policy changes on the living conditions of single mothers and their children. Studies of those leaving welfare have found that a substantial percentage have problems paying rent, purchasing enough food, and paying utility bills. Other studies have found a decline in income among the worst-off single mothers. The goal of this paper is to examine the material well-being of single mothers and their families before and soon after welfare reform. Using data from two nationally representative household surveys we examine the consumption patterns of single mothers and their families. We find that the material conditions of single mothers did not decline in recent years, either in absolute terms or relative to single childless women or married mothers. In most cases, our evidence suggests that the material conditions of single mothers have improved slightly, even for highly disadvantaged single mothers.
\end{abstract}

\author{
Bruce D. Meyer \\ Department of Economics and \\ Institute for Policy Research \\ Northwestern University \\ 2003 Sheridan Road \\ Evanston, IL 60208 \\ and NBER \\ bmeyer@northwestern.edu
}

James X. Sullivan Department of Economics and Institute for Policy Research Northwestern University 2003 Sheridan Road Evanston, IL 60208 


\section{Introduction}

Recently, state and federal policy makers dramatically changed tax and transfer programs for single mothers. The changes encouraged work and discouraged welfare receipt. Welfare and tax reform began in the mid-1980s and had many elements, culminating with the Personal Responsibility and Work Opportunity Reconciliation Act of 1996 (PRWORA) that "ended welfare as we knew it." Welfare caseloads declined by more than 40 percent in the four years after their peak in March of 1994, and the increases in employment and earnings of single mothers sharply accelerated after 1993.

Two recent studies found that total family income (including transfers) fell after 1994 for single mothers near the bottom of the income distribution. Moreover, studies of those leaving welfare have found that a substantial percentage of leavers have problems providing enough food, paying utility bills, and paying rent. The goal of this paper is to examine the material conditions of single mothers and their families before and soon after welfare reform in order to assess the net effect of recent policy changes on the well-being of these families. Using data from the Consumer Expenditure Survey and the Panel Study of Income Dynamics we examine the consumption patterns of single mothers and their families. We examine both absolute changes in the consumption of single mothers and changes relative to those for single women without children and married mothers.

We focus on consumption for two main reasons. First, economic theory suggests that consumption is usually a better measure of well-being than income. Consumption captures longterm income prospects including anticipated future income, while current income is likely to be disproportionately influenced by transitory fluctuations. Consumption is a more direct measure of well-being and includes the effect of in-kind transfers that income misses. Second, income tends to be under-reported. A substantial enthnographic literature indicates extensive underreporting of earnings and private transfers by welfare recipients. Other research indicates that there has been substantial under-reporting of government transfers and that this under-reporting has increased in recent years in key survey datasets. These observations are supported by direct comparisons from survey data that show consumption sharply exceeding income for those near the bottom. Of particular importance for evaluating welfare reform is the likelihood that under- 
reporting is different for single mothers than other groups, partly due to program incentives, and that this difference has changed over time.

By looking at single mothers we concentrate on the at risk population that is most likely to be affected by the recent reforms. Single mother families account for about 90 percent of the cash assistance caseload, they receive two-thirds of the credit dollars distributed through the EITC, and they are also the primary beneficiaries of many of the in-kind transfer programs. A large percentage of all single mothers benefit directly from tax and welfare programs. For example, in 1996 more than one-third of all single mother families received means-tested cash transfers. In this analysis, we concentrate on two groups that are likely to be affected by recent reforms, all single mothers and low-educated single mothers. We choose these groups because current welfare recipients or those leaving the rolls are not the only women affected by welfare reform. ${ }^{1}$ The increased state discretion under waivers and PRWORA combined with political changes has led to reforms which discourage welfare receipt and often divert potential welfare recipients from traditional programs. Under these conditions, it is likely that the characteristics of those on or leaving welfare will change sharply over time.

In the following section we highlight some of the key features of the reforms in tax and welfare policies that have taken place over the past decade. In Section III, we provide a brief overview of the vast and growing literature on welfare reform. This section is followed by a discussion of why consumption is a better proxy for material well-being than income, and a description of our sources of consumption data. In Section V, we outline our methodology and present the descriptive results for both single mother households and the comparison groups. Section VI discusses our main results from regressions that look at the absolute and relative changes in consumption for the average household and for those near the bottom of the consumption distribution, controlling for household characteristics. The robustness of these results are further investigated in section VII. We offer conclusions in section VIII.

\footnotetext{
${ }^{1}$ See National Research Council (1999) and Jencks and Swingle (2000) for related arguments.
} 


\section{Policies, Caseloads, and Employment}

The 1980s and 1990s was a period of experimentation and rapid change in the tax and transfer programs for single mothers. PRWORA was only a part of the changes and occurred at the end of the period we examine. Early in this period, states reduced real welfare benefits and increased the share of benefits kept by those working. Substantial change took place under welfare waivers - applications to the Secretary of Health and Human Services to change certain program requirements for AFDC (Aid to Families with Dependent Children). Between January 1993 and August 1996, 43 states had waivers approved. The most common waivers imposed work requirements and time limits, loosened asset restrictions and restrictions on two-parent families, or applied family benefit caps. Nevertheless, because of implementation lags and experimental waivers, until 1995 only a small fraction of women were in states which had implemented major changes under waivers.

The passage of PRWORA in 1996 accelerated this gradual overhaul of the welfare system. AFDC was replaced by state administered Temporary Assistance for Needy Families (TANF) block grants. Also added were mandated work requirements, time limits, and additional stipulations for minor parents that required them to live with an adult and work toward a high school degree. Besides these new requirements, PRWORA left the design of welfare programs up to the discretion of each state. The states have responded with a range of programs that differ widely in their eligibility requirements, time limits, and earnings disregards, as well as in additional provisions such as training and childcare.

At the same time that policy makers were remaking welfare policy, the nature of other tax and transfer programs that affect single mothers also changed. The Earned Income Tax Credit (EITC) grew nearly nineteen-fold over fifteen years, from $\$ 1.6$ billion in 1984 to $\$ 30$ billion in 1999. ${ }^{2}$ About two-thirds of the credit dollars go to single parents. ${ }^{3}$ The generosity of the EITC

\footnotetext{
${ }^{2}$ See Committee on Ways and Means (2000), table 13-14. The 1999 figure is projected. These figures are in nominal terms; in real terms EITC outlays grew by a factor of 9.7 during this time period. For a description and history of the EITC see Liebman (1998).

${ }^{3}$ Using figures from Committee on Ways and Means (1996) Table 14-13 and IRS (1996) Table 2.5 we calculate that approximately 68 percent of total EITC dollars went to single parents in 1996.
} 
increased following the Tax Reform Act of 1986 and also expanded every year from 1991 to 1996. These increases resulted in a substantial rise in the after-tax income of working single mothers. After-tax income for single mothers with annual earnings of $\$ 7,500$ and at least two children, for example, increased by more than $\$ 1,500$ from 1993 to $1996 .{ }^{4}$ Although the parameters of the credit did not change in real terms after 1996, it is likely that there was a lagged effect as women became more aware of the changes over the next year or two. ${ }^{5}$

Medicaid also significantly expanded during this time period. The expansions allowed many single mothers and/or their children to continue to receive medical coverage when their earnings increased. Medicaid caseloads for families with dependent children increased by 60 percent between 1984 and 1994 while expenditures increased by a factor of three for these families.

In addition to these changes, after 1984 there were large increases in federal and state child care spending; training programs were expanded and reoriented; and state income tax provisions affecting the poor were changed. These policies are described in detail in Meyer and Rosenbaum (2000, forthcoming).

The preceding discussion indicates that many policy changes potentially affecting the well-being of single mothers began well before the passage of PRWORA in 1996. Furthermore, the changes were not limited to cash transfer programs, as in-kind transfers and taxes also changed dramatically. Given this wide variety and uncertain timing of the policy changes, we examine changes in employment and welfare caseloads to assess when we might expect the conditions of single mothers to change. Table 1 reports the employment rate of single mothers and two comparison groups for the years 1984-1998. The employment rate of single mothers increased sharply after 1993, in absolute terms and relative to single women without children or married mothers. Already by 1996 the employment rate of single mothers was six percentage points higher than it was in 1993 . The increase in employment seems to roughly coincide with a sharp decline in welfare receipt. Figure 1 shows the AFDC/TANF caseload for 1963-1998. The

\footnotetext{
${ }^{4}$ See Meyer and Rosenbaum (2000).

${ }^{5}$ Both Eissa and Liebman (1996) and Meyer and Rosenbaum (forthcoming) find evidence of a lagged effect of EITC changes.
} 
number of families on welfare rose steeply to a peak in March 1994 and then fell sharply afterwards. Both the sharp increase in employment and rapid dropout in welfare caseloads preceded the passage of PRWORA by over two years.

The magnitude of the contribution of various policies and the macroeconomy to these changes is a subject on which there is a small literature. Meyer and Rosenbaum (2000, forthcoming) find that the EITC is responsible for a large share of employment increases through 1996, with a smaller, but still important role for welfare benefit cuts and changes in welfare programs under waivers. ${ }^{6}$ Improvement in the macroeconomy also increased the employment of single mothers, but had a very similar effect on single women without children. The welfare caseload literature (Levine and Whitmore 1998, Blank 1997, Ziliak et al. 1997) has reached conflicting results about the relative importance of waivers and macroeconomic conditions. For the purposes of this paper, we will be agnostic about the relative importance of different policies in changing the employment and welfare receipt of single mothers in recent years, as we are estimating the aggregate effect of many reforms independent of macroeconomic effects rather than identifying the specific effect of any single reform.

\section{Previous Research on the Effects of Welfare Reform}

Not surprisingly, the reforms discussed in the previous section have motivated an extensive amount of research on the effects of these policy changes on the well-being of single mothers. Most of the research evaluating the effects of welfare reform on well-being takes one of three forms: analyses of the outcomes of former welfare recipients after they leave the rolls (leaver studies); evaluations of the effects of policy changes within a state using randomized experiments; or comparisons of outcomes between states, exploiting the heterogeneity in reforms between two or more states. Moving beyond these generally state specific studies, some recent research has used nationally representative data to evaluate the broader effects of welfare reform,

\footnotetext{
${ }^{6}$ Also see Ellwood (2000), who attributes recent employment increases to welfare reform, the EITC, and improvements in macroeconomic conditions. Dickert et al. (1995) and Keane (1995) simulated recent tax changes (before they were implemented) and predicted employment changes somewhat larger than those that occurred.
} 
as this study does. Although each of these methodological approaches has its shortcomings, this early work on welfare reform provides useful insights on the well-being of single mothers.

More than a dozen welfare leaver studies examine how former welfare recipients have fared since leaving the rolls. ${ }^{7}$ These studies differ noticeably in the types of families followed, the frequency and duration of follow-ups, and the nature of questions asked. Nevertheless, some broad generalizations can be drawn. These studies show that a majority of former recipients have worked since leaving welfare - the employment rate varies from 53 percent to 88 percent across studies. In most cases, welfare leavers are employed in low wage jobs. In general, these studies suggest that the family incomes of leavers tend to be lower or similar to their combined earnings and benefits before exit, but poor family income data often limit the conclusions that can be drawn. There is some evidence that former welfare recipients are more likely to experience hardships such as difficulty providing food, paying utilities, or paying rent after exiting welfare, but questions on hardships were asked in only a few of the leaver studies.

Although these studies provide an interesting description of families leaving welfare in certain states, they have methodological problems. Due to significant differences in the design of these studies, it is very difficult to compare results across the studies. These studies fail to consider how welfare leavers are doing relative to the counterfactual-if they had remained on the rolls. The lack of a control group and historical information makes it extremely difficult to draw causal inferences about the effects of reforms. Lastly, leaver studies only evaluate the effects of welfare reform on those who exit, ignoring the likely effects that recent reforms have in discouraging families from applying for assistance and the potential effects on those that remain participants.

Randomized social experiments are another common methodology used to evaluate welfare policy. These experiments, generally conducted at the state or county level, compare the outcomes of two groups of welfare applicants: a control group that participates in a program under the pre-reform policies, and a treatment group that is subject to the new provisions of welfare reform in that state. For example, an experiment conducted in Indiana separated a

\footnotetext{
${ }^{7}$ The General Accounting Office (GAO 1999) discusses 18 state-sponsored leaver studies. See the National Research Council (1999) and Brauner and Loprest (1999) for other summaries of leaver studies.
} 
sample of families who applied for welfare at a point in 1995 into treatment and control groups, and followed these families for two years. ${ }^{8}$ Preliminary results from this experiment suggest that reforms in Indiana increased the average share of income from earnings, but average total income did not rise. The results also show that although there were modest employment gains as a result of reforms for a select group of "employment ready" participants, after two years there was little evidence of a difference in employment between the treatment and control groups. A second example is the experimental evaluation of Florida's Family Transition Program that evaluated the combination of a small earnings supplement (a larger earnings disregard), a time limit on receipt of welfare benefits, and some job finding services. ${ }^{9}$ This combination, which is similar in some respects to policies undertaken more recently in other states, seems to have improved the material well-being of recipients. For the group subject to the new program, the incidence of housing and neighborhood problems was significantly lower, and food consumption was higher, though not significantly.

Experimental designs yield more persuasive evidence than other approaches because the randomization enables these studies to isolate the effects of changes in a policy, avoiding problems that arise when other factors, such as in the macroeconomy or demographics, change simultaneously with policy reforms. Unfortunately, these studies also have drawbacks. First, it is difficult to make inferences about the overall effects of welfare reform from evaluations of a few program elements for the populations in a few localities. This is particularly true because of the pronounced heterogeneity in the nature of reforms across states. Second, these experiments took place at a time when perceptions about welfare and the culture within welfare offices were changing dramatically. Given this reform-oriented environment researchers are likely to have a difficult time insulating control group participants from these changes. Consequently, these experiments are not immune to biases due to spillover and imitation effects. Probably the greatest difficultly with experimental evidence is that randomization occurs when individuals apply for benefits. Thus, the experimental studies fail to capture the effects of reforms on nonapplicants. Lastly, experiments have focused on changes in cash assistance policies, leaving

\footnotetext{
${ }^{8}$ See Holcomb et al. (1998) for a description of this experiment and a summary of the results.

${ }^{9}$ See Bloom et al. (2000) for a description of this experiment and a summary of the results.
} 
unexamined other components of reform that some researchers have found to be crucial, such as the EITC and Medicaid.

Other research has identified the effects of different reforms by comparing outcomes across states. These cross-state studies compare outcomes from individuals in one state where a particular reform has been implemented to individuals in another state with similar welfare policies, but where the reform has not been implemented. For example, in an evaluation of the Wisconsin Works welfare reform program, Wiseman (1999) compares employment, poverty, and material well-being outcomes for low income families in Wisconsin to similar families in Michigan and Minnesota, and to national averages. Wiseman (1999) identifies the effects of the Wisconsin Works program by exploiting the fact that Wisconsin emphasized work and termination of assistance, while Michigan's policies focused on encouraging work while on the rolls, and Minnesota's policies were much more lenient with respect to work requirements. This study suggests that different welfare reform strategies in neighboring states produced similar results in terms of poverty, employment, and material well-being. Although it is clear that the nature of reforms differed across these states, the precise nature of these differences is difficult to characterize for the purposes of evaluation. The difficulty of characterizing the differences in reforms across states is a major obstacle for these cross-state studies. ${ }^{10}$ Furthermore, the complex nature of many state reforms makes it difficult to evaluate specific aspects of reforms and to extrapolate the results to other localities.

Due to the limitations of state-level studies, other researchers have turned to nationally representative data. Bavier (1999) and Primus et al. (1999) both analyze how the income of single mother headed families has changed in the midst of welfare reform using repeated crosssectional data from the Current Population Survey (CPS). Both studies show that although family incomes for the poorest segments of single mothers rose from 1993 to 1995, incomes for these families fell in the 1996-1997 period. Because losses in transfer income outstripped earnings gains in these years, the results suggest that the recent reforms such as PRWORA made this population worse off. These papers would benefit from examining comparison groups in

\footnotetext{
${ }^{10}$ See Ellwood (2000) for a version of this argument.
} 
order to disentangle the effects of changes in welfare policies from changes in the macroeconomic environment. Moreover, it would be useful to supplement the income data with additional information given the under-reporting of income, especially means-tested transfer income, and given questions about the accuracy of imputations of taxes and tax credits in the CPS.

Schoeni and Blank (2000) also use the CPS in their study of the effects of welfare reform. They use both a difference-in-differences methodology-comparing less educated women to more educated women - and cross state variation in the timing of welfare reform implementation to identify the effects of reforms on a variety of outcomes. Their results suggest that policy changes in the 1990s resulted in caseload reductions, higher family incomes, and a decline in poverty. They found no evidence that income increased in response to TANF reforms, though some of their results suggest that family incomes for less-skilled women increased in response to waivers, primarily as a result of increased employment for these women.

The majority of the studies evaluating the effects of welfare reform concentrate on outcomes such as earnings, employment, poverty status, family structure, or welfare dependence. ${ }^{11}$ Research designs that use these outcomes are particularly important for evaluating whether welfare reform is successfully achieving explicit goals such as ending dependence, promoting work, and reducing non-marital childbirth. By themselves, however, these outcomes provide little evidence on the overall effects of reforms on well-being. Other studies look at the effects of welfare reform on the well-being of single mothers and their families by monitoring the changes in family income of welfare eligible families in light of recent reforms. Using income as a proxy for well-being can be problematic particularly for the evaluation of the well-being of low income groups, not only because of under-reporting of public assistance income, but also because almost all single mothers supplement their income with informal employment and money from family or friends. These sources of income generally are not captured in survey data (Edin and Lein, 1997). To avoid many of these shortcomings we focus on family consumption as a proxy

\footnotetext{
${ }^{11}$ For an excellent review of studies of welfare reform and a discussion of various outcomes used in these studies see National Research Council (1999).
} 
for the material well-being of single mothers. Consumption is arguably the best proxy for wellbeing available for empirical research, and expenditures are less likely to be susceptible to the reporting errors that often plague measures of family income. We discuss these issues further in the following section.

\section{Data}

To measure the material well-being of single mothers, we focus on consumption data rather than income data, for two primary reasons. First, income systematically understates the financial resources available to a household. Second, consumption is a more direct measure of well-being than income. Furthermore, the measurement problems with income appear particularly problematic for intertemporal analyses of the well-being of single mothers because the biases have changed over time, and they are correlated with welfare and tax reform.

Income is likely to understate material well-being in several ways. As numerous studies have documented, national surveys under-report family income. For low income households, this under-reporting problem is exacerbated by the prevalence of off-the-books income and transfers. Ethnographic research has shown that almost all single mothers supplement their income with informal employment and money or goods from family and friends. These sources of support from informal sources and the underground economy generally are not captured in survey data on income (Edin and Lein 1997).

The problem of understated income is exacerbated by changes in the extent of underreporting that are likely related to recent policy changes. For example, with diminished dependence on cash transfers with their high implicit tax rates, there is a reduced incentive to hide income. AFDC caseloads fell dramatically after March of 1994, reducing the incentive for single mothers to hide income. Consequently, reported income for these households might rise even if the true value of income does not change. ${ }^{12}$ Incentives to under-report income were also

\footnotetext{
${ }^{12}$ Mayer and Jencks (1993) provide evidence for an earlier period that the growth in both means-tested transfers and illegitimate income resulted in an increase in the under-reporting of income.
} 
changed by recent EITC expansions that increased the incentive to substitute on-the-books earnings (which would be partially matched by credit dollars) for off-the-books income.

In addition to the under-reporting of earnings and private transfers, household surveys also fail to capture the full value of government transfers, particularly for single mothers. Underreporting of means-tested cash transfers has increased in recent years (Bavier, 1999), which would imply that recent measured changes in income are biased downward. Comparisons of CPS numbers to administrative data suggest that by 1993 unreported means-tested cash transfers were equal to over 11 percent of total reported income for single mothers in the bottom income quintile. Overall, unreported cash transfers grew by 68 percent from 1993 to 1997. Assuming households at the bottom under-report these transfers at the same rate as all welfare recipients, this rise in under-reporting alone would bias downward measured changes over this period in income for single mothers in the bottom income quintile by nearly 8 percentage points. ${ }^{13}$

Under-reporting is not the only reason that income measures are likely to understate the financial wherewithal of households. Income data also fail to capture in-kind transfers, such as food stamps, that are reflected in expenditure data. These in-kind transfers are a particularly important source of support for households with low cash incomes. Recent changes in Medicaid are likely to substantially affect family well-being without affecting measured family income. On the other hand, non-medical consumption measures would reflect Medicaid changes. Whether income changes understate or overstate well-being changes as a result of reforms in Medicaid policy is unclear. If families are less likely to receive Medicaid when they leave AFDC/TANF now than in the past, then changes in income would overstate changes in wellbeing. On the other hand, for families that became eligible for health benefits as a result of recent Medicaid expansions, changes in income would understate changes in well-being.

Income also fails to capture the insurance value of means tested transfers. If welfare is a valuable source of insurance for poor households, then the value of this insurance falls as welfare reform introduces more rigid eligibility rules such as time limits and work requirements. This

\footnotetext{
${ }^{13}$ This figure is based on the authors' calculations using CPS and administrative data reported in Bavier (1999).
} 
creates an incentive for these households to find alternative sources of insurance such as increased savings. Again, the loss of insurance due to a weaker safety net would not reduce income, but could reduce consumption as families save for a rainy day. Also, income measures fail to capture disparities in consumption that result from differences across households in the accumulation of assets or access to credit (Cutler and Katz, 1991).

Certainly, consumption is measured with error as well. There is less evidence, however, that these errors have changed systematically over time, or that they are correlated with changes in welfare. Households do not have the same incentives to under-report consumption, so there is little reason to suspect that the rate at which households mis-report consumption has changed over time. Furthermore, consumption data should capture changes in welfare policy that are overlooked using income measures. The consumption behavior of the household should reflect, for example, the effects of changes in Medicaid eligibility or changes in the insurance value of welfare.

Evidence from survey data shows that the disparity between income and consumption is particularly evident for single mothers. A comparison of total after-tax household income-including earnings and transfers for all family members-to total household expenditures from 1984 to 1998 shows that expenditures exceed income by an average of 14 percent for single mother households. ${ }^{14}$ For single mothers who have a high school degree or less education, the disparity is even larger-16 percent on average from 1984 to 1998-suggesting that income numbers are a more problematic measure of well-being for less-skilled single mothers; precisely the demographic group most directly affected by recent changes in government transfer policies. The relationship between consumption and income follows a different pattern for other types of households. Single women without children outspent total income by less than 3 percent on

\footnotetext{
${ }^{14}$ Comparisons of income and consumption data are based on the authors' calculations from Consumer Expenditure Survey (CEX) data. For this analysis we restrict attention to consumer units in the CEX that are "complete" income reporters. Between 10 and 15 percent of all consumer units are classified as incomplete income reporters by the BLS because of missing data for primary sources of income for these households.
} 
average during the period of our sample, while two parent families had income that exceeded expenditures by more than 9 percent on average, implying a higher rate of saving by these households.

Economic theory suggests that current expenditures serve as a better proxy for the material well-being of the household than current income. ${ }^{15}$ Current income can be a misleading indicator of the economic status of the household because earnings are susceptible to temporary fluctuations due to transitory events such as layoffs or changes in family status. These temporary changes cause current income to vary more than consumption, but they do not necessarily reflect changes in well-being. Also, while current income only reflects short term resources, consumption is more likely to capture a household's forward looking behavior, thus avoiding the volatility associated with short term fluctuations in income. Furthermore, Poterba (1991) provides evidence that the difference between current income and current expenditures is larger for very young and very old households, suggesting that some of this disparity is likely the result of life-cycle behavior, and that current income understates well-being for these households.

Research looking at both household income and expenditures shows that reported income falls well short of reported expenditures, and studies looking at the relationship between income and well-being have argued that income is only weakly correlated with material hardship (Mayer and Jencks 1989). These weaknesses with income data as well as the more direct relationship between consumption and material well-being provide a strong argument for exploiting household expenditure data in an analysis of well-being. Although household expenditures do ignore many important components of well-being such as physical and mental health, neighborhood and school quality, and family functioning, expenditures are arguably the best aggregate measure of the material well-being of a household.

We draw on two different sources for expenditure data: the Consumer Expenditure Survey (CEX) and the Panel Study of Income Dynamics (PSID). We use both datasets to provide two independent sources of evidence on the consumption of single mothers and because

\footnotetext{
${ }^{15}$ For further discussion see Cutler and Katz (1991), Slesnick (1993), or Poterba (1991).
} 
each dataset has its strengths and weaknesses. We can then report on the patterns that are similar in the two sources.

The CEX is a nationally representative survey conducted by the Bureau of Labor Statistics (BLS) that is designed to provide a continuous summary of the spending habits of U.S. households. Among other uses, these data are the basis for updating the expenditure weights used in the calculation of the Consumer Price Index. This rotating panel survey interviews approximately 5,000 households quarterly and follows each household for up to five consecutive quarters. ${ }^{16}$ The BLS estimates that the survey accounts for up to 95 percent of all household expenditures, making it the most comprehensive survey on household consumption. ${ }^{17}$ The CEX also reports detailed information on demographic characteristics as well as employment and income information for each member of the household.

Observations in the CEX are organized by consumer unit, which generally refers to all related members in a household. Unrelated individuals that pool their incomes to make joint expenditure decisions are also classified as a single consumer unit (for ease of exposition "consumer unit" and "household" will be used interchangeably). Expenditure measures are provided at the household level only. ${ }^{18}$

From total expenditures for each household, we construct a measure of total current consumption by excluding spending that can be construed as an investment. Thus, our main outcome variable, total consumption, includes all household expenditures less spending on education and health care, cash contributions, and outlays for retirement including pensions and social security. In addition to total consumption, we report spending on a few of the components

\footnotetext{
${ }^{16}$ Many households fail to complete all four interviews. For a discussion of attrition in the CEX and its effects on our analysis see the Data Appendix.

${ }^{17}$ Hamermesh and Slesnick (1995) assert that the CEX is "the only source of satisfactory spending data in the United States."

${ }^{18}$ Because the CEX does not provide data on consumption at the subfamily level our sample will not include single mothers who reside in a household with their parents. To address concerns about how this might bias our results, we looked at subfamily patterns from the CPS. The ratio of single mother subfamilies to all single mother families has remained remarkably steady at about 0.2 throughout the period from 1987 to 1998 . The fact that the prevalence of single mother subfamilies has changed very little over time suggests the following analysis is less vulnerable to bias that may result from failing to observe consumption at the subfamily level.
} 
of this total. Food consumption includes spending on food at home, spending on food away from home, and food stamps received but excludes food received as pay. Work expenses include spending on domestic services and child care, while child care expenses are a subcomponent of work expenses. Discretionary spending reflects household outlays for alcoholic beverages, tobacco, entertainment, reading materials, and apparel. To address concerns about the lumpy nature of expenditures on durables, we convert reported housing and vehicle spending to service flow equivalents. Refer to the Data Appendix for a more detailed description of the CEX data.

The PSID is an annual longitudinal survey that has followed a nationally representative random sample of families, their offspring, and coresidents since 1968. The survey provides detailed economic and demographic information on both the household and individual level for a sample of about 7,000 households each year. The PSID is a primary source of high quality panel data on household income and labor force participation. Unlike the CEX, the PSID follows households that relocate.

Although the PSID does not survey households about all expenditures, it does collect data on household food expenditures. We construct a measure of total food consumption as the sum of expenditures on food at home, expenditures on food away from home, and dollars of food stamps received. To make this measure consistent with CEX figures, we report these expenditures in quarterly terms. A more detailed description of PSID data is also provided in the Data Appendix.

From the CEX we construct a sample of household-quarter observations, and from the PSID our unit of observation is a household-year. To analyze consumption behavior throughout this period of welfare reform we draw on data from 1984 through $1998 .{ }^{19}$ For both surveys, we restrict attention to households whose head is between the ages of 18 and 54 and whose family type falls into one of the following categories: single mothers with at least one child less than 18 years old, single women without children, and married mothers with at least one child less than 18. In addition, we exclude any observation with a non-positive measure of quarterly food consumption.

\footnotetext{
${ }^{19}$ From the CEX we include data from the first quarter of 1984 wave through the first quarter of 1999 wave. From the PSID we include data from the 1984 wave through the 1997 wave.
} 


\section{Methodology and Descriptive Results}

As discussed in Section III, a common problem with many of the recent evaluations of welfare reform, particularly the leaver studies, is that they only consider the effects of policy changes on former recipients. Given that diversion of potential applicants was an important component of recent reforms, ${ }^{20}$ this approach ignores the impact of policy changes on nonparticipants. It is likely that the characteristics of the population of welfare recipients have also changed as caseloads sharply increased and then fell steeply. For these reasons, some researchers have concluded that looking at all single mothers is the only way to evaluate the overall effects of welfare reform. ${ }^{21}$ By looking at single mothers we focus on the at risk population that is most likely to be affected by the recent reforms. About 40 percent of all single mother households received means-tested cash benefits in $1991 .^{22}$ This fraction dropped to 36 percent by 1996 and to less than 30 percent by 1998. In 1996, 35 percent of all single mother households received food stamps, while more than 60 percent benefitted from the EITC. For single mothers with a high school degree or less, 54 percent received cash benefits in 1991, but this dropped to 47 percent in 1996 and to 43 percent by 1998. More than 40 percent of these less educated single mothers received food stamps in 1996 and 62 percent received the EITC. Single mother families account for about 90 percent of the cash assistance caseload, they receive twothirds of the credit dollars distributed through the EITC, and they are also the primary beneficiaries of many of the in-kind transfer programs discussed in Section II.

To simplify the presentation of our results, we group the years from 1984 through 1998 into four distinct time periods. The first period, 1984 to 1990, ended before implementation of most of the significant policy changes discussed in Section II. The period from 1991 to 1993

\footnotetext{
${ }^{20}$ Diversion has taken many forms ranging from placing potential applicants in more appropriate programs to discouraging welfare receipt through onerous requirements.

${ }^{21}$ For example, see Jencks and Swingle (2000).

${ }^{22}$ These figures are based on the authors' calculations using CPS data for female household heads between the ages of 18 and 54 with children less than 18 years old. The fraction of single mothers receiving cash transfers is adjusted using figures from Bavier (1999) to reflect under-reporting of these transfers in the CPS.
} 
coincided with the start of the major expansions in the EITC. Welfare waivers were also starting to appear in several states during this time. In the following period, 1994 to 1995, waivers became noticeably more prevalent, the EITC continued to expand, caseloads started a steep decline, and trends in employment for single mothers changed noticeably. In the final period from 1996 to 1998, waivers continued, PRWORA was passed and implemented, and the EITC expansions were completed. ${ }^{23}$

A major obstacle to any non-experimental analysis of the impact of policy changes is that it is difficult to disentangle the effects of these changes from the effects of changes in macroeconomic conditions. This problem may be particularly important for the case of welfare reform given the prolonged economic expansion that took place in the 1990s. While we also estimate specifications controlling for unemployment rates, out main approach is to compare consumption changes for single mothers to those for other groups. By selecting an appropriate comparison group we may be able to control for these macroeconomic changes. Ideally, this comparison group would be affected by economic changes in the same way as single mothers but would not be affected by the changes in tax and welfare policy. We focus on the relative effects of welfare reform on all single mothers using two separate comparison groups: single women without children and married mothers. All three groups of women have similar wages, and this similarity is especially strong when one conditions on educational attainment. ${ }^{24}$ Although this approach will not enable us to identify the separate effects of specific reforms, it should provide evidence on how the series of dramatic changes in welfare and tax policy has affected the wellbeing of single mothers.

Tables 2 and 3 provide summary descriptive statistics for each of these three groups in the CEX and the PSID respectively. ${ }^{25}$ Each panel in the tables provides information for a single time

\footnotetext{
${ }^{23}$ While these periods are somewhat arbitrary, we have confirmed that our analyses are not sensitive to the exact division of the years. For example, if 1996 is included with the 1994-1995 period our results do not change qualitatively.

${ }^{24}$ For additional evidence supporting the validity of single women without children as a comparison group see Meyer and Rosenbaum (2000, forthcoming), who find that employment for the two groups responds in an extremely similar way to changes in aggregate unemployment.

${ }^{25}$ In both the CEX and the PSID a single household may remain in the survey's sample for multiple waves. The standard errors reported in Tables 2 through 7 are corrected for this within household correlation by bootstrapping. We calculate bootstrap standard errors by resampling at the household
} 
period. Both data sources paint a similar picture. Single mothers in these samples are less educated and are more likely to be minorities than either single women without children or married mothers. The mean age is fairly similar across the three groups. The differences between single mothers and the comparison groups (seen by comparing columns 4 and 5 across panels) remain fairly stable over time. The relative means for educational attainment, family size and racial background change very little between 1984 and 1998, though all three groups become somewhat more educated over time, and this increase in educational attainment is slightly more noticeable for single mothers. None of the changes in educational attainment for single mothers relative to single childless women are significantly different from zero. In the CEX, however, the changes in educational attainment relative to married mothers from the 1984-1990 period to the 1996-1998 period are significant. In the PSID, we see a significant rise from 1984-1990 to 1996-1998 in the fraction of single mothers that attain only a high school degree relative to this fraction for married mothers. Consistent with the employment data from the CPS reported in Table 1, the employment rate for single mothers in both the CEX and PSID increases noticeably in recent years both in absolute and relative terms. ${ }^{26}$ The employment rate of single women without children falls gradually over our sample period, while employment increases slightly for married mothers. The rise in the employment rate of single mothers relative to single women without children from 1984-1990 to 1996-1998 is statistically significant in both the CEX and the PSID. In the CEX, the rise in the employment of single mothers relative to both comparison groups from 1994-1995 to 1996-1998 is also statistically significant.

Tables 4 and 5 provide the same statistics as the previous tables, restricting attention to households headed by a woman with a high school degree or less. Within this less educated group, single mothers again have fewer years of education, are less likely to work, and are more likely to be minorities than the comparison groups. Again, family size and race change very little both in absolute and relative terms. Since the 1984-1990 period, low-skilled single women have become slightly more educated. This increase is significant relative to married mothers in the

level, taking all observations for a given household, rather than at the household-year (PSID) or household-quarter (CEX) level. These bootstrap standard errors are estimated using 200 replications. ${ }^{26}$ The employment measure is the percentage of each group of women that report having worked for at least one week in the 12 months prior to the interview. 
CEX. We also see an increase in the percentage of low-skilled single mothers who work relative to the control groups. As is the case with all single women, the rate of employment of less educated single mothers rises relative to the employment of less educated single women without children from 1984-1990 to 1996-1998, and this increase is statistically significant in both the CEX and the PSID.

In order to evaluate how the relative well-being of single mothers changes over the sample period, we compare the changes in the consumption levels of single mothers to the changes in consumption levels of our comparison groups. The mean quarterly levels of various components of consumption from the CEX and food consumption from the PSID are reported in Table $6 .{ }^{27}$ The means from the CEX show that total consumption changes little over time in real terms for all three groups of women. (To see this, compare total consumption in columns 1-3 across panels). For single mothers, we see almost no change in total consumption from 19841990 through 1994-1995. After 1994-1995, consumption by single mothers increases significantly from $\$ 4,597$ in the $1994-1995$ period to $\$ 4,933$ in the following period. Between our first and last periods, the level of total consumption for single mothers rises by more than 7 percent in real terms, a statistically significant increase. Consumption rises for both comparison groups over this same period as well, although these increases are much smaller (about 3 percent), and for single women without children this rise is not significantly different from zero.

The results for relative total consumption over time (compare columns 4 and 5 across panels) show that single mothers on average experience a slight drop in relative consumption after the 1984-1990 period, but relative consumption subsequently rises in the 1996-1998 period. This pattern is more evident relative to single women without children, while consumption relative to married mothers changes very little, rising slightly in the most recent period. Changes between 1994-1995 and 1996-1998 show that consumption for single mothers rises significantly by 8.4 percentage points relative to single women without children. For this same period, consumption for single mothers rises by 2.6 percentage points relative to married mothers, but this change is not significantly different from zero.

\footnotetext{
${ }^{27}$ All consumption figures are converted to 1995:2 dollars using the Personal Consumption Expenditure deflator reported by the Bureau of Economic Analysis.
} 
Looking at some of the components of total consumption reported in Table 6, data on food consumption from both the CEX and the PSID show that the recent rise in relative consumption for single mothers is not driven by an increase in spending on food. Relative food consumption does not change noticeably, falling only slightly after the 1984-1990 period in the CEX relative to single childless women, but changing very little thereafter. None of the changes in relative food consumption in the CEX are significantly different from zero. In the PSID, only the change in food consumption for single mothers from 1984-1990 to 1994-1995 relative to married mothers is significant. Both housing and discretionary spending for single mothers relative to the comparison groups rise in the most recent years, with discretionary spending increasing by 10 percentage points and housing rising by 6.3 percentage points from 1994-1995 to 1996-1998 relative to single childless women. However, neither of these increases are significant. The only statistically significant increase in discretionary spending is the 14 percentage point rise relative to single childless women from 1984-1990 to 1996-1998. The pattern for work related expenditures is consistent with the marked increase in the relative employment rates of single mothers after 1993. Both work expenses and child care spending increase for single mothers relative to married mothers after 1993, but these changes are not statistically significant. ${ }^{28}$ In any case, the magnitude of child care and work expenses is too small to account for much of the changes in aggregate consumption.

We report these same results for our more restricted sample of women with a high school degree or less in Table 7. The rise in consumption in recent years is much less noticeable for these less skilled women than for the sample of all women. Total consumption for less skilled single mothers remains virtually unchanged throughout our sample period, falling only slightly in the 1991-1993 period. Total consumption for both of the less skilled comparison groups falls modestly between the 1984-1990 period and the 1996-1998 period, resulting in a small rise in relative consumption for single mothers between these periods. None of these changes in relative total consumption, however, are statistically significant. The components of total consumption

\footnotetext{
${ }^{28}$ While average child care expenses are small here, they are consistent with numbers reported in Blau (2000) once one accounts for the fact that the mothers in our samples are low income, many do not work in a typical week, and the vast majority do not pay for child care.
} 
also change little over time. In the CEX, food consumption and housing expenditures fall for less educated single mothers relative to less educated single women without children in the early 1990s, although these changes are not statistically significant. In the PSID, food consumption for less educated single mothers relative to less educated married mothers is significantly lower in 1984-1990 than in any of the three following periods, but food consumption relative to lowskilled single women without children does not change significantly. Discretionary spending falls for all three groups in the 1991-1993 period and changes little in subsequent periods. Comparing discretionary spending for less educated single women with and without children, relative discretionary spending increases significantly from 1984-1990 to 1991-1993 for single mothers, but this change is driven by a drop in discretionary spending by single childless women. Relative discretionary spending remains unchanged after 1993.

Interesting patterns are evident in these descriptive results from the CEX and the PSID. First, consumption for single mothers relative to single women without children remains virtually unchanged in the years preceding 1996 and rises in the short period following. Second, relative to married mothers, consumption for single mothers also varies only slightly during this period, rising in more recent years, although this increase is less noticeable than the rise relative to single childless women. Third, changes in total consumption are reflected through changes in housing, discretionary spending, and other consumption categories more than through changes in food consumption. Lastly, patterns of relative consumption for less skilled women do not change noticeably during our sample period. None of these results, however, condition on differences in household demographics or control for how these demographics may change over time. For this reason, in the following section we employ regression methods in order to better isolate the effects of recent policy changes on the relative consumption of single mothers.

\section{Mean and Quantile Regressions Accounting for Household Characteristics}

By comparing single mothers to single women without children and married mothers we can isolate the impact of changes in welfare policy, which affect single mothers differently than the comparison groups, from the impact of other changes in the economic environment, which 
arguably affect all three groups similarly. Changes in the differences in mean consumption, however, may also result from changes in the characteristics of those in one of these three groups.

To isolate the effects of changes in policies we estimate regression models of the following form:

$$
\ln \left(\mathrm{C}_{\mathrm{iq}}\right)=\beta_{1}+\mathrm{SM}_{\mathrm{i}}^{*} \text { PERIOD }_{\mathrm{iq}} \beta_{2}+\text { PERIOD }_{\mathrm{iq}} \beta_{3}+\mathrm{X}_{\mathrm{iq}} \beta_{4}+\mathrm{M}_{\mathrm{iq}} \beta_{5}+\varepsilon_{\mathrm{iq}}
$$

where the dependent variable is $\log$ consumption for household $\mathrm{i}$ in quarter $\mathrm{q} ; \mathrm{SM}_{\mathrm{i}}$ is an indicator for whether the household head is a single mother; PERIOD iq is a vector of indicators for each of the four time periods discussed earlier, 1984-1990, 1991-1993, 1994-1995, or 1996-1998 (19961997 for the PSID); $X_{\mathrm{iq}}$ is a vector of demographic characteristics including family size and age composition measures as well as race, educational attainment, and a cubic in age for the female family head; ${ }^{29} \mathrm{M}_{\mathrm{iq}}$ is a vector of month dummies indicating the specific months during which the expenditures take place; ${ }^{30}$ and $\varepsilon_{\mathrm{iq}}$ is a household-quarter error term. Each element of the vector $\beta_{2}$ represents the effect on log consumption of being a single mother in a particular period relative to being in one of our comparison groups. Thus, comparisons of the components of this vector of parameter estimates indicate how the relative consumption of single mothers changes across periods. For example, to examine how consumption for single mothers relative to single women without children changes between 1994-1995 and 1996-1998, we estimate equation (1) for our sample of single women. The coefficient on the interaction term $\mathrm{SM}_{\mathrm{i}}{ }^{*}(1994-1995)_{\mathrm{i}}$ from this estimation can be interpreted as the ratio minus one of consumption for single mothers to

\footnotetext{
${ }^{29}$ We experimented with different controls for family size and age composition in order to measure different households in equivalent terms. Our results are not notably sensitive to how we control for family size and composition. All results reported in the paper are from specifications which include a third order polynomial in the number of children and adults in the household, as well as controls for the number of children less than 6 years old and the number of children between 6 and 11 years old.

${ }^{30}$ Month dummies are only included for the CEX samples. The month dummies capture seasonal differences in consumption behavior. We use monthly rather than quarterly dummies to account for the fact that quarterly consumption was approximated using monthly expenditure data. We weight the month dummies in order to appropriately reflect seasonality; each month dummy takes on a value equal to the number of times that month's expenditures are counted towards quarterly expenditures. For example, if an observation's only reported expenditures for the fourth quarter are for the month of October then the October dummy would equal 3 and all other month dummies would equal zero.
} 
consumption for single women without children in the 1994-1995 period, while the coefficient on $\mathrm{SM}_{\mathrm{i}}{ }^{*}(1996-1998)_{\mathrm{iq}}$ yields this same ratio for the 1996-1998 period. ${ }^{31}$ Thus, the difference between these two coefficients can be interpreted as the percentage point change in the relative consumption of single mothers between these two periods.

To capture the relative change in expenditures, we estimate equation (1) for four separate samples_all single women, all mothers, less educated single women, and less educated mothers - using both mean and quantile regressions. We employ both regression models in order to allow policy effects to differ at different points in the consumption distribution. The mean regressions estimate the effect of policy changes for the average single mother, while our quantile regressions estimate the policy effects for those at either the $25^{\text {th }}$ percentile or the $15^{\text {th }}$ percentile of the consumption distribution.

In Figure 2 we plot the estimated year effects from equation (1) for two samples: all single mothers and less educated single mothers. We exclude the comparison group interaction terms and use single year dummies rather than period dummies in order to show how the level of total consumption changes from 1984 through 1998 for single mother households. The 1984 year dummy is excluded so that the figure represents changes in the level of consumption relative to 1984 . Total consumption for single mothers begins to rise after 1988, and rises more noticeably after 1993. Moreover, this pattern is evident not only for single mothers with average consumption levels but also for those at both the $15^{\text {th }}$ and $25^{\text {th }}$ percentiles of the consumption distribution, as well as for less educated single mothers.

The estimates for equation (1), excluding the interaction terms, for these same samples of

\footnotetext{
${ }^{31}$ This is true because consumption is expressed in log terms, and for small changes the difference between two logged values is approximately equal to the percentage change: $\ln (a)-\ln (b) \approx(a-b) / b$, for small $|(a-b) / b|$.
} 
single mothers are presented in Table 8. ${ }^{32,33}$ Consistent with Figure 2, the point estimates in Table 8 show that consumption levels for single mothers are higher after 1990. Across all five specifications, total consumption is significantly higher in 1996-1998 than in 1984-1990. For example, consumption for a single mother at the $25^{\text {th }}$ percentile in $1996-1998$ is 9.8 percent higher than consumption for a single mother at the $25^{\text {th }}$ percentile in 1984-1990, and for less educated single mothers, the level of consumption is 12.4 percent higher at the $25^{\text {th }}$ percentile in this later period. Total consumption for single mothers in 1996-1998 is also significantly higher than consumption in 1991-1993 across all specifications. These results provide strong evidence that, conditioning on household characteristics, the level of consumption for less educated single mothers is higher in the 1996-1998 period than either of the periods prior to 1994. Although the point estimates suggest that consumption rises from 1994-1995 to 1996-1998, this increase is only significant when comparing single mothers at the $15^{\text {th }}$ percentile where total consumption increases by 9.3 percentage points (p-value: 0.0148). We also examine whether consumption for single mothers does not fall appreciably over time. In nearly every case we can reject the hypothesis that the level of consumption for single mothers in a given period falls by more than 5 percent relative to the previous periods. This is true for all single mothers as well as for less educated single mothers.

Tables 9 through 11 report estimates for equation (1) showing how relative consumption for single mothers changes during our sample period. Results for total consumption in the CEX (see Table 9) are fairly consistent with the results for mean consumption reported in Tables 6 and 7. Although the means suggest that relative consumption rises only after 1994-1995,

\footnotetext{
${ }^{32}$ As with the descriptive statistics, the standard errors reported in Tables 8-11 are corrected for within household correlation. For the mean regressions the conventional White estimator is used. For the quantile regressions we calculate bootstrap standard errors by resampling at the household level, taking all observations for a given household, rather than at the household-year (PSID) or household-quarter (CEX) level. Again, we use 200 replications to estimate these bootstrap standard errors. This correction increases the magnitude of our standard errors by a factor of about 1.95 on average with the increase ranging from a factor of 1.5 to 2.6.

${ }^{33}$ The p-values reported in Tables 8 through 11 reflect a high covariance between the estimates for different time periods when we include flexible controls for family size and composition. Since the standard errors of the time period coefficients also increase, the precision of our estimates for changes in relative consumption over time are not appreciably affected.
} 
conditioning on family demographics the rise in relative consumption for single mothers appears to begin after 1984-1990. Looking at the results for single women (in the odd numbered columns in Table 9), total consumption for single mothers relative to single women without children is higher in the 1996-1998 period than in any of the earlier periods. Comparing 1984-1990 to 1996-1998, relative consumption is higher in the later period relative to both comparison groups. This rise in relative consumption is significant across all specifications except when comparing less educated single women at the $15^{\text {th }}$ percentile, where consumption rises by 10.3 percentage points $(23.0 \%-12.7 \%)$, a weakly significant increase (p-value: 0.0783$)$. There is some evidence that consumption for single mothers relative to single women without children rises slightly between the 1994-1995 period and the 1996-1998 period, and this rise is slightly more evident for all single women (columns 3 and 7) than for less educated single women (columns 5 and 9). None of these changes, however, are statistically different from zero.

Although these estimates provide some evidence that total consumption for single mothers relative to single childless women is higher in 1996-1998 than in 1984-1990, we cannot make conclusive statements about changes in relative consumption for single mothers after 1990. These results do show, however, that relative consumption for single mothers does not fall noticeably after 1990. For example, we can reject the null hypothesis that consumption for single mothers relative to single women without children falls by more than 5 percentage points from 1991-1993 to 1996-1998 across all specifications except for less educated single women at the $15^{\text {th }}$ percentile. Moreover, looking at the results for all single women (columns 3 and 7) we can reject the hypothesis that the relative consumption of single mothers falls by more than 5 percentage points between 1994-1995 and 1996-1998.

Estimates for changes in total consumption for single women without children (captured by the period dummy coefficients in the odd numbered columns in Table 9) suggest that the level of consumption for this comparison group did not change much over time. In only one case is the estimated drop for single women without children from 1984-90 to 1996-1998 greater than 1.49 percent, and the estimates are never significantly different from zero. This result implies that only a small fraction of any increase in relative consumption for single mothers can be explained by a fall in consumption for single childless women. 
The results comparing the total consumption behavior of mothers (in the even numbered columns in Table 9) are similar to those for single women. Across all specifications the consumption of single mothers relative to married mothers rises over time. Between 1984-1990 and 1996-1998 relative consumption rises by more than 10 percentage points, and this increase is significant in each specification. For mothers at the $25^{\text {th }}$ percentile, for example, relative consumption increases significantly by 12.8 percentage points $(0.464-0.336)$. Looking at more recent changes suggest that relative consumption for single mothers increases by 2 to 7 percentage points between 1994-1995 and 1996-1997. These changes, however, are only marginally significant for a single mother at the $25^{\text {th }}$ percentile of all mothers (column 4; p-value: 0.0509 ) or at the $15^{\text {th }}$ percentile of all mothers (column 8; p-value: 0.0537). Again, the results provide fairly strong evidence that relative consumption for single mothers does not fall during this period of reforms. Other than the period from 1991-1993 to 1994-1995, we can consistently reject the hypotheses that consumption for single mothers relative to married mothers falls by more than 5 percentage points over time.

Looking at the year effects for the sample of mothers shows that although the level of consumption for married mothers drops after 1984-1990 this only partially explains the rise in the relative consumption of single mothers. Much of the fall in consumption for married mothers occurs between 1984-1990 and 1991-1993 where consumption drops significantly by 2.5 to 4.7 percent. After 1991-1993, however, consumption for married mothers remains unchanged or increases slightly.

Figures 3 and 4 provide a summary of the results for changes in relative total consumption reported in Table 9. In these figures we plot the coefficients on the interaction term from equation (1), using single year dummies rather than period dummies, for a sample of all single women (Figure 3) and of all mothers (Figure 4). The interaction of the single mother household indicator with the 1984 year dummy is excluded so that the figures represent changes in relative consumption since 1984. Figure 3 shows that consumption for single mothers relative to single women without kids falls noticeably between 1984 and 1987, but then rises steadily after 1989. This trend is fairly similar at different points in the consumption distribution, and for different levels of educational attainment. Figure 4 shows that relative to married mothers, 
consumption for single mothers remains steady from 1984 to 1989 and then rises modestly from 1989 to 1991 . After 1991 relative consumption falls slightly, but it rises noticeably after 1994.

Tables 10 and 11 report estimates from the CEX and the PSID respectively using food consumption as the outcome variable. The estimates from the CEX in Table 10 show little change in relative food consumption over time using either comparison group. Very few of the changes over time in relative food consumption for single women are statistically different from zero. Looking at the results for single women (the odd columns in Table 10), the point estimates suggest that relative food consumption for single mothers falls from 1984-1990 to 1996-1998, but these changes are small, ranging from 1.1 to 6.6 percentage points, and either not significant or only weakly significant.

The results for food consumption for mothers (even columns) show that food consumption for single mothers rises slightly over time relative to married mothers. In a few cases, the rise in relative food consumption from 1984-1990 to either 1994-1995 or 1996-1998 is significant. For a single mother at the $25^{\text {th }}$ percentile $1996-1998$ relative food consumption rises by 4.5 percentage points, a weakly significant rise (p-value: 0.0605 ), and at the $15^{\text {th }}$ percentile relative food consumption rises significantly by 5.3 percentage points ( $\mathrm{p}$-value: 0.0450 ). Increases in relative food consumption are also evident for the less educated sample of mothers. The rise in relative food consumption for a less educated single mother with average food consumption is significant (p-value: 0.0098). This change, however is only weakly significant for a low-skilled single mother at the $15^{\text {th }}$ percentile (p-value: 0.0924$)$, and the increase is not significant for a low-skilled single mother at the $25^{\text {th }}$ percentile (p-value: 0.1827 ). For this sample of mothers we can usually reject the hypothesis that relative food consumption for single mothers falls by more than 5 percentage points over time.

The results for food consumption from the PSID in Table 11 follow a fairly similar pattern as the results reported in Table 10, although the results for the PSID are somewhat less precise due to smaller sample sizes. Consistent with the results reported for the CEX, most changes over time in the food consumption for single mothers relative to single women without children are not significantly different from zero. Looking at the results for single women in the PSID, however, there is some evidence that relative food consumption rises from 1994-1995 to 
1996-1997. For example, relative food consumption rises significantly by 18.4 percentage points (p-value: 0.0393 ) for a less educated single mother at the $25^{\text {th }}$ percentile and by 15.5 percentage points (p-value: 0.0089) for a single mother at the $15^{\text {th }}$ percentile. All other changes in relative consumption for single women are not significantly different from zero. Across all specifications for single women, we can reject the hypothesis that relative food consumption for single mothers falls by more than 5 percentage points from 1994-1995 to 1996-1997. In most cases we can also reject this hypothesis for changes in relative consumption between 1991-1993 and 1996-1997.

Relative food consumption for single mothers also rises relative to married mothers. Between 1984-1990 and 1996-1997 this increase in relative food consumption ranges from 10.6 to 16.8 percentage points and is significant for all specifications. These changes in relative consumption can be explained in part by a drop in food consumption by married mothers of more than 7 percent during this time. In all cases, we reject the hypothesis that food consumption for single mothers relative to married mothers falls by more than 5 percentage points between 19841990 and any of the following periods.

In sum, these estimates from the CEX and the PSID indicate how the relative material well-being of single mothers has changed in response to the reforms enacted throughout the past decade. There is substantial evidence that total consumption by single mothers increases from 1984-1990 to 1996-1998 in absolute terms and relative to both single women without children and married mothers. This increase in consumption does not appear to be driven by work expenses or child care costs. The results reported in Tables 8-11 consistently show that consumption for single mothers does not fall appreciably in either absolute or relative terms during this period of reforms after 1990. Consumption during this period for less skilled single mothers and for single mothers near the bottom of the consumption distribution follow a similar pattern. In cases where there is evidence of increases in relative consumption for single mothers, only some of the gains can be explained by a drop in consumption for the comparison groups. The estimates suggest that this period of reform did not have a negative impact on the relative material well-being of single mothers. In fact, we repeatedly reject the null hypothesis that relative total consumption falls by more than 5 percentage points after the 1984-1990 period. Comparing relative consumption in 1996-1998 to 1994-1995 shows only a small, insignificant 
increase in relative consumption for single mothers. Again, however, there is some significant evidence that relative consumption does not fall appreciably during this time, suggesting that the relative material well-being of single mothers has not fallen in response to the reforms implemented in 1996.

\section{Other Estimates and Checks on the Results}

While part of the favorable situation of single mothers that we found above is likely due to improved macroeconomic conditions in the later years that we examine, we do not believe that it is a large part of the explanation for several reasons. First, the baseline period of 1984-1990 was a time of growth and low unemployment. Second, we see similar patterns in consumption if we compare single mothers to single women without children or to married mothers or if we compare the low educated among either of these groups. Finally, our results are fairly consistent at different points in the consumption distribution for these groups.

As a check on whether changes in macroeconomic conditions have a significant effect on the relative consumption of single mothers, we also estimate versions of the specifications reported in Tables 9 and 11, where we add controls for either the national or state unemployment rate and its interaction with being a single mother. ${ }^{34}$ In general, the addition of unemployment controls does not change our results for the changes in relative consumption for single mothers. We do not emphasize these estimates for two reasons. First, we lose some precision as sample sizes fall because the BLS suppresses the state identifier for some respondents. Second, especially with the national unemployment rate, we cannot convincingly identify the effects of economic conditions given that there is one recession during our sample period. A related issue is that we obtain counter-intuitive results for the cyclicality of consumption in some specifications. In the CEX sample, our estimates with these unemployment controls lead to conclusions that are similar to those from the estimates without unemployment controls.

\footnotetext{
${ }^{34}$ Results using the state unemployment rate are only feasible with the CEX data because the PSID early release data from 1994 through 1997 do not have state identifiers.
} 
Looking at the results for single women, in most specifications both groups of single women fare slightly better in low unemployment times, though the estimates of the effects of unemployment on consumption are very noisy. The results including unemployment controls for the total consumption of single mothers relative to married mothers also follow a very similar pattern as those reported without these controls. For mothers, the unemployment rate coefficients are contrary to expectation in some specifications, with single mothers estimated to have slightly higher consumption when the unemployment rate is higher, while married mothers have lower consumption under worse economic conditions. Again these estimates are very imprecise. In the PSID sample, the estimates corresponding to Table 11, but with unemployment controls, have roughly the same pattern as those without the controls. The estimates for changes in relative food consumption, however, are much less precise than those reported without unemployment controls. For single mothers relative to single women without children the estimates with unemployment controls imply greater relative increases in consumption in the last two years for single mothers than do the estimates without controls. Again, some of the unemployment effects are contrary to expectation. Higher unemployment is generally associated with higher consumption for both single mothers and married mothers, while single childless women fare worse in times of high unemployment.

\section{Conclusions}

In the 1990s the U.S. saw some of the most notable reforms in government tax and transfer programs since President Johnson declared a war on poverty in 1964. Implementation of state waivers in the early to mid-1990s initiated an overhaul of the welfare system, which culminated with the passage of PRWORA in 1996. During this same time, new state and federal programs were created and others including the EITC were expanded to boost the earnings and work incentives for low income families.

These reforms had some clear and immediate consequences. Caseloads fell by more than 40 percent from their peak in 1994. Employment rates for single mothers increased by 12 percent from 1993 to 1998, and their earnings grew in real terms. Despite this significant 
increase in earnings, reductions in transfer income resulted in lower total income for some single mothers in some datasets, implying that the net effect of these reforms on the well-being of single mothers is unclear. This paper analyzes the consumption of single mothers and their children in absolute terms and relative to comparison groups in order to determine how the material wellbeing of single mothers has changed in the midst of these reforms.

Our results show that the level of total expenditures for single mothers increases slightly in real terms throughout this period. In relative terms, there is some evidence that consumption for single mothers near the bottom of the consumption distribution increased over the 1990s, and this increase is also noticeable for less skilled single mothers. In most cases, we see a statistically significant increase in relative total consumption for single mothers between 19841990 and 1996-1998. Our results also show that some of these gains in consumption for single mothers occur after 1995, but these changes are quite small and in many cases not statistically significant. Nevertheless, across our different specifications we can repeatedly reject the hypothesis that relative consumption fell by more than 5 percentage points, providing strong evidence that the material well-being of single mothers has not appreciably declined as a result of recent reforms.

This evaluation of the effects of welfare reform adds to the existing literature in several ways. First, by looking at all single mothers, as opposed to only those on welfare, we are able to capture both the direct effect of reforms on current and past recipients, as well as effects on those induced not to receive welfare. Second, we use household consumption to evaluate the effects of welfare reform on the well-being of single mothers. Consumption is likely to be a better proxy for well-being than income, and is less likely to be under-reported than income, particularly for poor families. Third, rather than just looking at levels of consumption, we compare the consumption behavior of single mothers to two separate comparison groups. Assuming other economic changes that occurred in the past decade affected single mothers and the comparison groups similarly, this approach enables us to isolate the effects of welfare and tax changes. Lastly, we are able to strengthen these initial findings by analyzing consumption behavior from two independent data sources. The similar patterns of consumption changes that emerge from the PSID and the CEX suggest that our results are fairly robust. 
This study provides a first look at how recent changes in tax and welfare policy have affected the material well-being of single mothers and their children. While consumption is arguably the best aggregate measure of material well-being, we should emphasize that it misses many important components of well-being such as physical and mental health, leisure, family functioning, and neighborhood and school quality. Our analysis is also restricted to short-term effects of policy changes since only a few years have passed since the most recent reforms were enacted. 


\section{Data Appendix}

Consumer Expenditure Survey: This survey, conducted by the Bureau of Labor Statistics (BLS), collects detailed expenditure data at the household level for a nationally representative sample. The survey also provides income and demographic information for each household (consumer unit). The BLS interviews approximately 5,000 households quarterly, and follows each household for five consecutive quarters, although many households do not remain in the sample for all five interviews. Data from the first of these interviews, which collects an inventory of household durables as well as demographic characteristics, are not publicly available. Each subsequent interview reports expenditures for the three months prior to the interview month. The household is dropped from the survey after the fifth interview. The survey does not follow households that relocate.

With this rotating panel design, one-fifth of the respondents are replaced each quarter. Interviews are conducted monthly, with about one-third of the sample surveyed each month. At each interview households are asked about expenditures for the previous three months, so only about one-third of the interviews report expenditures according to actual calendar quarters (i.e. those interviewed in January, April, July, or October), while expenditures reported by the other two-thirds will span two consecutive quarters. For households that do not report spending according to an actual calendar quarter schedule, expenditures are allocated to the appropriate calendar quarter by linking expenditure data across interviews. For example, consider a household that is interviewed twice: in March (reporting expenditures for December, January and February) and June (reporting expenditures for March, April, and May). We calculate first quarter expenditures by combining January and February expenditures reported in the March interview with March expenditures reported in the June interview. If a household reports only one or two months of expenditures for any calendar quarter, spending is extrapolated. Referring to the previous example, we only have two months of recorded expenditures for the second calendar quarter. In this case we would approximate second quarter expenditures by multiplying the sum of expenditures in April and May by 1.5. Following this procedure, we construct a sample of household-quarter observations. 
From total expenditures for each household, we construct a measure of total current consumption, by excluding spending that can be construed as an investment. Our measure of total consumption includes all household expenditures less spending on education, health care, cash contributions, and outlays for retirement including pensions and social security. Included in total consumption, are all other expenditures made by the household for itself or others. This spending includes all sales and excise taxes but excludes all reimbursed and business related expenditures.

To address concerns about the lumpy nature of expenditures on durables, we convert reported housing and vehicle spending to service flow equivalents. To capture housing flows, we subtract from total expenditures mortgage interest payments, property tax payments, and spending on insurance, maintenance and repairs, and add to total expenditures the self-reported rental equivalent value of the home. ${ }^{35}$ This procedure partly follows Cutler and Katz (1991).

For vehicles, we estimate the value of new car purchases for each household that owns a car, and calculate a service flow that is a function of this predicted value of new vehicle purchases and the age of each vehicle the household owns assuming a constant geometric vehicle depreciation of 5 percent per quarter. ${ }^{36}$ Again following the lead of Cutler and Katz (1991), the predicted value of new car purchases is generated for all households that own a vehicle. Using the sample of households that report a purchase of a new car in the three months prior to the interview, we regress actual expenditures for new vehicles on total expenditures (less new vehicle expenditures), expenditures squared, the age and education level of the consumer unit, a set of household type dummies interacted with family size, and a set of year dummies. Parameter estimates from this regression are then used to predict the value of new vehicle purchases, $V_{i}$, for each household that owns a vehicle. Vehicle service flows, $S_{i}$, for household $i$ with $\mathrm{N}$ vehicles

\footnotetext{
${ }^{35}$ CEX surveys from the third quarter of 1993 through the fourth quarter of 1994 did not ask home owners about the rental equivalent of the home. This value is imputed by regressing the rental equivalent on the reported market value of the home and a set of household type dummies for households from our sample between 1990 and 1998 for whom rental equivalent and market value are observed. The parameter estimates from this regression are then used to predict the rental equivalent for households for which these data are not available.

${ }^{36}$ This depreciation method follows research on the depreciation of automobiles; depreciation rates generated from this functional form are fairly consistent with automobile valuation analysis using data on the sale price of used cars (Peles, 1988).
} 
which were produced $t_{j}$ quarters ago for $j=1, \ldots, N$, are specified as:

$$
S_{i}=V_{i} * \sum_{j=1}^{N} \delta(1-\delta)^{t_{j}}
$$

where $\delta$ is the quarterly depreciation rate. These flows are generated for cars and trucks only; spending on other types of vehicles are excluded from total consumption.

In addition to total consumption, we also look at components of consumption spending. Food consumption includes spending on food at home, spending on food away from home, and food stamps received, but excludes food received as pay. Work expenses include spending on domestic services and child care, while child care expenses are a subcomponent of work expenses. Discretionary spending reflects household outlays for alcoholic beverages; tobacco; entertainment expenses such as spending on sporting events, movies, television, radio, pets, and hobbies; reading materials such as newspapers, magazines, books, and encyclopedias; and apparel including spending on clothes and footwear for both adults and children.

The BLS does make an effort to address concerns about a household's ability to accurately recall all expenditures. The interview surveys, which have a recall period of three months, a relatively short period compared to most income surveys, compile data on major expenditures such as housing, transportation or large durables quarterly through a series of detailed questions that itemize each purchase separately. The BLS estimates that these questions account for 60 to 70 percent of all household expenditures. For smaller or more frequent purchases, the BLS constructs estimates of quarterly expenditures by asking each household to report spending on broad categories such as quarterly expenditures at grocery stores. These expenses are estimated to account for 20 to 25 percent of total household expenditures. Together these quarterly surveys account for approximately 80 to 95 percent of all expenditures. The BLS frequently compares expenditure measures from the CEX with other expenditure data for quality evaluation. Branch (1994), for example, compares various components of expenditures from the CEX to several different data sources, and finds these independent sources of expenditure data to 
be fairly consistent. For more information on the CEX see Bureau of Labor Statistics (1997).

A potential concern with CEX data is the degree of attrition bias (Bavier 2000). While attrition rates have always been high in the CEX, these rates have increased in recent years. This increase in attrition rates could be particularly problematic if they are different for single mothers than for our comparison groups, or if those who dropped out were systematically different from those who remain in the survey for all four quarters ("stayers"). For example, if single mothers who drop out of the sample are more likely to have low levels of consumption than single mothers that remain in the sample, then an increase in attrition over time would provide spurious evidence suggesting consumption for single mothers has increased. Furthermore, if attrition rates were more stable for comparison groups, then we might spuriously conclude that the relative consumption of single mothers had increased.

In order to determine whether attrition has biased our results from the CEX, we take a closer look at attrition rates and how they have changed over time. While about 60 percent of single mothers remained in the sample for all four reported interviews for the years from 1989 through 1994, this number drops to around one-half in 1995, and to about 40 percent in 1996 and 1997. Much of the increase in attrition that occurs in 1995 can be explained by a sample redesign, but the reasons for high attrition in subsequent years are unclear. A similar pattern of attrition rates is evident for less educated single mothers, while single mothers in the bottom quartile of the consumption distribution show higher increases in attrition in recent years. Attrition rates for single women without children are higher than those for single mothers, but the changes in attrition rates over time are similar for both groups.

More important for our analysis is whether consumption behavior for stayers and nonstayers differs, and whether this difference changes over time. We found little evidence that attrition is correlated with the consumption behavior of single mothers. Average total expenditures for single mothers that remain in the sample do not differ noticeably from the expenditures of single mothers that do not complete all interviews.

Attrition does seem to be a bit more problematic for our comparison groups. For single women without children, for example, stayers consume more than non-stayers. The average consumption of stayers relative to non-stayers, however, falls over time, implying that stayers in 
later years do not clearly consume more. Nevertheless, the changes in the consumption patterns of stayers relative to non-stayers give rise to concerns about the possibility of attrition bias in our comparison group. As a test of this bias, we estimate equation (1) using only the first reported interview for each household in our CEX sample. Using this restricted sample, the results for single women do not change qualitatively, and while some of the estimates for mothers change, the numbers still indicate that relative consumption did not fall for single mothers during our sample period.

Panel Study of Income Dynamics: The PSID is a nationally representative panel survey conducted by the Survey Research Center at the University of Michigan. This annual longitudinal survey has followed a random sample of families, their offspring, and coresidents since 1968. The survey provides detailed economic and demographic information on both the household and individual level for a sample of about 7,000 households each year. The PSID is a primary source of high quality panel data on household income and labor force participation. Unlike the CEX, the PSID follows households that relocate.

Although the PSID does not ask households about all expenditures, it does collect data on household food consumption. As with the CEX, consumption is only available at the household level. The 1988 and 1989 waves did not include questions on food expenditures, but in all other years for our sample the questionnaire asks, "in addition to what you bought with food stamps, did you spend any money on food that you used at home?" Respondents are also asked about the food expenditures of the household outside of the home and receipt of food stamps in the month prior to the interview. As several other studies have argued (see Zeldes 1989, Gruber 1997), it is likely that the respondent will report consumption levels at the time of the interview. For this reason, we interpret the consumption response as pertaining to the interview year rather than the previous year. We construct a measure of total food consumption as the sum of expenditures on food at home, expenditures on food away from home, and dollars of food stamps received. We report all expenditures in quarterly terms to be consistent with the figures from the CEX. 


\section{References:}

Bavier, Richard, “An Early Look at the Effects of Welfare Reform,” mimeo, March 1999.

Bavier, Richard, "What's Going on in the Bottom Quintile," mimeo, January 2000.

Blank, Rebecca M., "What Causes Public Assistance Caseloads to Grow?" NBER Working Paper No. 6343, May 1997.

Blau, David M., “Child Care Subsidy Programs," NBER Working Paper No. 7806, July 2000.

Bloom, Dan, James J. Kemple, Pamela Morris, Susan Scrivener, Nandita Verma, and Richard Hendra, "FTP: Final Results of Florida's Initial Time-Limited Welfare Program," (New York: Manpower Demonstration Research Corporation, December 2000).

Branch, E. Raphael, “The Consumer Expenditure Survey: A Comparative Analysis," Monthly Labor Review, December (1994), 47-55.

Brauner, Sarah and Pamela Loprest, "Where are They Now? What States' Studies of People Who Left Welfare Tell Us," (Washington, D.C.: The Urban Institute, 1999).

Bureau of Labor Statistics, "Consumer Expenditures and Income," in BLS Handbook of Methods, U.S. Department of Labor, 1997.

Cutler, David M. and Lawrence F. Katz, "Macroeconomic Performance and the Disadvantaged," Brookings Papers on Economic Activity, 2: 1991, 1-74.

Dickert, Stacy, Scott Houser, and John Karl Scholz, "The Earned Income Tax Credit and Transfer Programs: A Study of Labor Market and Program Participation," in Tax Policy and the Economy 9, James M. Poterba, ed. (Cambridge, MA: MIT Press, 1995), 1-50.

Edin, Kathryn and Laura Lein, Making Ends Meet: How Single Mothers Survive Welfare and Low-Wage Work, (New York: Russell Sage Foundation, 1997).

Eissa, Nada and Jeffrey B. Liebman, "Labor Supply Response to the Earned Income Tax Credit," Quarterly Journal of Economics, CXII (1996), 605-637.

Ellwood, David T., "The Impact of the Earned Income Tax Credit and Social Policy Reforms on Work, Marriage and Living Arrangements," National Tax Journal, 53:4 Pt.2 (December 2000), 1063-1106.

Falk, G. "Consumption Expenditures for Families with Children," mimeo, Congressional Research Service, July 2000.

General Accounting Office, "Welfare Reform: Information on Former Recipients' Status," (Washington, DC: GAO/HEHS-99-48, April 1999).

Gruber, Jonathan, "The Consumption Smoothing Benefits of Unemployment Insurance," American Economic Review, 87:1 (1997), 192-205.

Hamermesh, Daniel S. and Daniel T. Slesnick, "Unemployment Insurance and Household 
Welfare: Microeconomic Evidence 1980-93,” NBER Working Paper No. 5315, October 1995.

Haskins, Ron, “The Second Most Important Issue: Effects of Welfare Reform on Family Income and Poverty," mimeo, U.S. House of Representatives, 2000.

Holcomb, Pamela A., Terri S. Thompson, Caroline E. Ratcliffe, David J. Fein, Erik Beecroft, William Hamilton and Wang S. Lee, "The Indiana Welfare Reform Evaluation: Program Implementation and Economic Impacts After Two Years," (Washington, D.C.: The Urban Institute and Abt Associates, 1998).

Jencks, Christopher and Joseph Swingle, "Without a Net," The American Prospect vol. 11 no. 4, January 3, 2000.

Keane, Michael, "A New Idea for Welfare Reform," Federal Reserve Bank of Minneapolis Quarterly Review, XXXVIII (1995), 2-28.

Levine, Phillip B. and Diane M. Whitmore, "The Impact of Welfare Reform on the AFDC Caseload," National Tax Association Proceedings, Ninetieth Annual Conference, (1998), 24-33.

Liebman, Jeffrey B., "The Impact of the Earned Income Tax Credit on Incentives and Income Distribution," in Tax Policy and the Economy 12, James M. Poterba, ed. (Cambridge, MA: MIT Press, 1998), 83-120.

Mayer, Susan E. and Christopher Jencks, "Poverty and the Distribution of Material Hardship," Journal of Human Resources, 24:1 (1989), 88-113.

, "Recent Trends in Economic Inequality in the United States: Income versus Expenditures versus Material Well-Being," in Poverty and Prosperity in the USA in the Late Twentieth Century, Edward N. Wolff, ed. (New York: St. Martin's Press, 1993), 121-203.

Meyer, Bruce D. and Dan T. Rosenbaum, "Welfare, the Earned Income Tax Credit, and the Labor Supply of Single Mothers," forthcoming, Quarterly Journal of Economics (NBER Working Paper Number 7363, September 1999).

, "Making Single Mothers Work: Recent Changes in Tax and Welfare Policy and their Effects," forthcoming, National Tax Journal, 53:4 Pt. 2 (December 2000), 1027-1062.

National Research Council, Evaluating Welfare Reform: A Framework and Review of Current Work, Robert Moffitt and Michele Ver Ploeg, eds. (Washington, DC: National Academy Press, 1999).

Peles, Yoram C., "On the Depreciation of Automobiles," International Journal of Transport Economics, 25:1 (1988), 43-54.

Poterba, James M., "Is the Gasoline Tax Regressive?" in Tax Policy and the Economy 5, David Bradford, ed. (Cambridge, MA: MIT Press, 1991), 145-164.

Primus, Wendell, Lynette Rawlings, Kathy Larin, and Kathryn Porter, "The Initial Impacts of Welfare Reform on the Incomes of Single-Mother Families," (Washington, DC: Center 
on Budget and Policy Priorities, 1999).

Schoeni, Robert F. and Rebecca M. Blank, "What has Welfare Reform Accomplished? Impacts on Welfare Participation, Employment, Income, Poverty, and Family Structure," NBER Working Paper No. 7627, March 2000.

Slesnick, Daniel T., "Gaining Ground: Poverty in the Postwar United States," Journal of Political Economy, 101:1 (1993), 1-38.

U.S. House of Representatives, Committee on Ways and Means, Green Book, Background Material and Data on Programs within the Jurisdiction of the Committee on Ways and Means, (Washington, DC: Government Printing Office, various years).

Wiseman, Michael, "In Midst of Reform: Wisconsin in 1997," (Washington, D.C.: The Urban Institute, 1999).

Zeldes, Stephen P., "Consumption and Liquidity Constraints: an Empirical Investigation," Journal of Political Economy, 97:2 (1989), 305-346.

Ziliak, James P., David N. Figlio, Elizabeth E. Davis, and Laura S. Connolly, "Accounting for the Decline in AFDC Caseloads: Welfare Reform or Economic Growth?" mimeo, July 1997. 
Figure 1

Monthly AFDC/TANF Caseloads (1963-1998)

(in Millions)

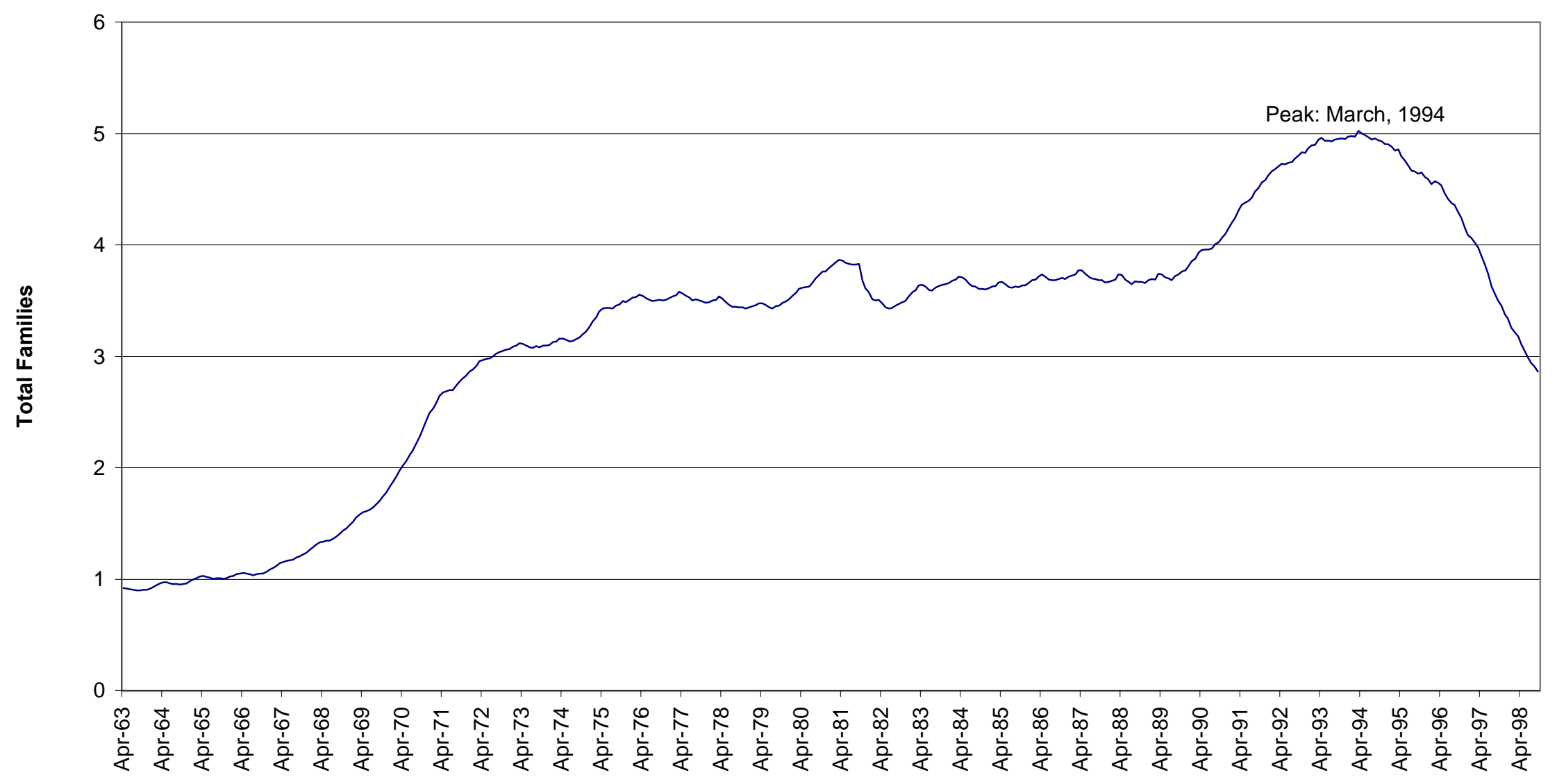

Notes: Caseload levels are based on reports from the Department of Health and Human Services. They represent total family caseloads, including AFDC-UP and child-only cases, from all 50 states as well as Washington D.C., but do not include cases from the U.S. territories. 

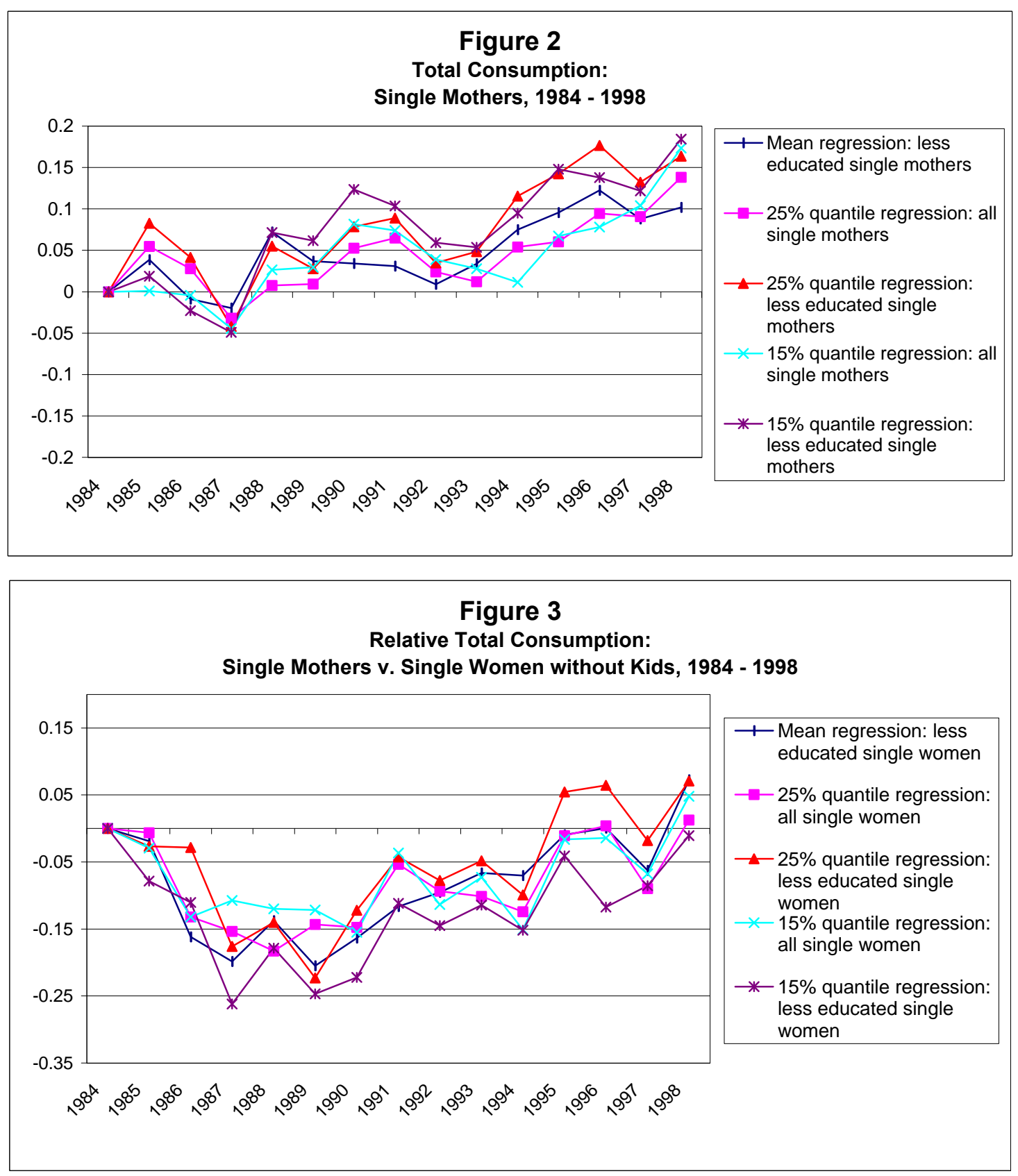

Figure 4

Relative Total Consumption:

Single Mothers v. Married Mothers, 1984 - 1998

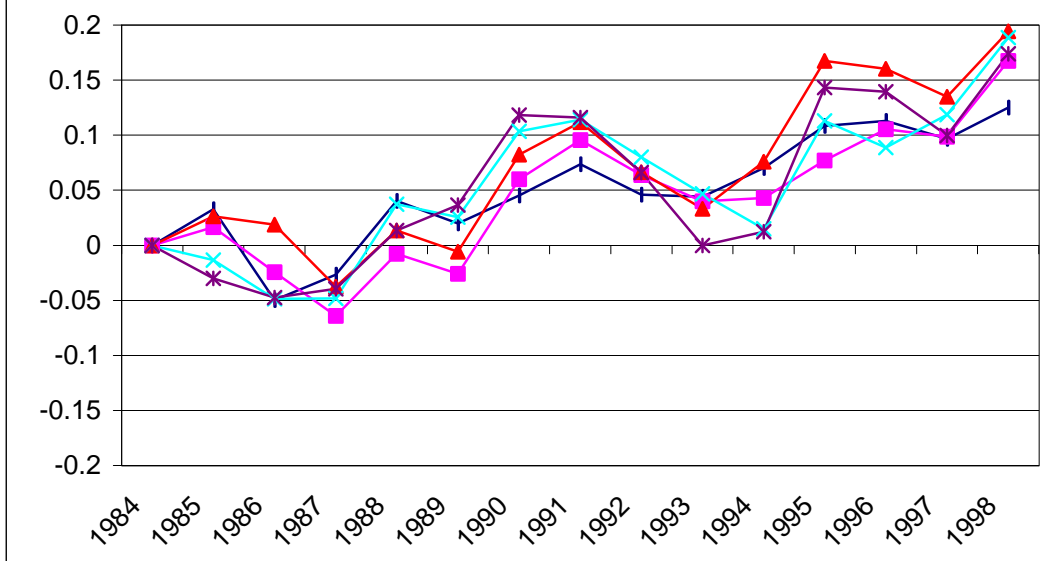

\begin{tabular}{|l|}
\hline- Mean regression: less \\
educated married women \\
$-25 \%$ quantile regression: all \\
married women \\
$\rightarrow-25 \%$ quantile regression: \\
less educated married \\
women \\
$\rightarrow-15 \%$ quantile regression: all \\
married women \\
$\rightarrow 15 \%$ quantile regression: \\
less educated married \\
women
\end{tabular} 


\section{Table 1}

\section{Employment Rates for Single Mother and Comparison Households Sample: Women Ages 18-54, CPS}

\begin{tabular}{|c|c|c|c|c|c|}
\hline \multirow[b]{2}{*}{ Year } & \multicolumn{3}{|c|}{ Worked Last Year } & \multirow[b]{2}{*}{$\begin{array}{l}\text { Difference } \\
(4)=(1)-(2)\end{array}$} & \multirow[b]{2}{*}{$\begin{array}{c}\text { Difference } \\
(5)=(1)-(3)\end{array}$} \\
\hline & $\begin{array}{c}\text { Single Mothers } \\
\text { (1) }\end{array}$ & $\begin{array}{l}\text { Single, no } \\
\text { Children } \\
\text { (2) }\end{array}$ & $\begin{array}{c}\text { Married Mothers } \\
\text { (3) }\end{array}$ & & \\
\hline 1984 & $\begin{array}{c}0.7900 \\
(0.0055)\end{array}$ & $\begin{array}{c}0.9381 \\
(0.0027)\end{array}$ & $\begin{array}{c}0.6840 \\
(0.0035)\end{array}$ & $\begin{array}{l}-0.1481 \\
(0.0061)\end{array}$ & $\begin{array}{c}0.1060 \\
(0.0065)\end{array}$ \\
\hline 1985 & $\begin{array}{c}0.7991 \\
(0.0056)\end{array}$ & $\begin{array}{c}0.9446 \\
(0.0025)\end{array}$ & $\begin{array}{c}0.6917 \\
(0.0035)\end{array}$ & $\begin{array}{l}-0.1455 \\
(0.0061)\end{array}$ & $\begin{array}{c}0.1074 \\
(0.0066)\end{array}$ \\
\hline 1986 & $\begin{array}{c}0.7934 \\
(0.0056)\end{array}$ & $\begin{array}{c}0.9423 \\
(0.0026)\end{array}$ & $\begin{array}{c}0.7148 \\
(0.0034)\end{array}$ & $\begin{array}{l}-0.1488 \\
(0.0061)\end{array}$ & $\begin{array}{c}0.0786 \\
(0.0065)\end{array}$ \\
\hline 1987 & $\begin{array}{c}0.7899 \\
(0.0056)\end{array}$ & $\begin{array}{c}0.9392 \\
(0.0026)\end{array}$ & $\begin{array}{c}0.7102 \\
(0.0035)\end{array}$ & $\begin{array}{l}-0.1493 \\
(0.0062)\end{array}$ & $\begin{array}{c}0.0797 \\
(0.0066)\end{array}$ \\
\hline 1988 & $\begin{array}{c}0.7855 \\
(0.0059)\end{array}$ & $\begin{array}{c}0.9454 \\
(0.0026)\end{array}$ & $\begin{array}{c}0.7195 \\
(0.0036)\end{array}$ & $\begin{array}{l}-0.1599 \\
(0.0065)\end{array}$ & $\begin{array}{c}0.0660 \\
(0.0069)\end{array}$ \\
\hline 1989 & $\begin{array}{c}0.7926 \\
(0.0056)\end{array}$ & $\begin{array}{c}0.9403 \\
(0.0025)\end{array}$ & $\begin{array}{c}0.7288 \\
(0.0034)\end{array}$ & $\begin{array}{l}-0.1477 \\
(0.0061)\end{array}$ & $\begin{array}{c}0.0638 \\
(0.0065)\end{array}$ \\
\hline 1990 & $\begin{array}{c}0.7899 \\
(0.0056)\end{array}$ & $\begin{array}{c}0.9419 \\
(0.0025)\end{array}$ & $\begin{array}{c}0.7263 \\
(0.0034)\end{array}$ & $\begin{array}{l}-0.1520 \\
(0.0061)\end{array}$ & $\begin{array}{c}0.0636 \\
(0.0066)\end{array}$ \\
\hline 1991 & $\begin{array}{c}0.7853 \\
(0.0056)\end{array}$ & $\begin{array}{c}0.9313 \\
(0.0027)\end{array}$ & $\begin{array}{l}0.7318 \\
(0.0034)\end{array}$ & $\begin{array}{l}-0.1459 \\
(0.0062)\end{array}$ & $\begin{array}{c}0.0535 \\
(0.0066)\end{array}$ \\
\hline 1992 & $\begin{array}{c}0.7767 \\
(0.0058)\end{array}$ & $\begin{array}{c}0.9287 \\
(0.0028)\end{array}$ & $\begin{array}{c}0.7300 \\
(0.0035)\end{array}$ & $\begin{array}{l}-0.1520 \\
(0.0064)\end{array}$ & $\begin{array}{c}0.0467 \\
(0.0067)\end{array}$ \\
\hline 1993 & $\begin{array}{c}0.7782 \\
(0.0058)\end{array}$ & $\begin{array}{c}0.9293 \\
(0.0028)\end{array}$ & $\begin{array}{c}0.7411 \\
(0.0035)\end{array}$ & $\begin{array}{l}-0.1512 \\
(0.0064)\end{array}$ & $\begin{array}{c}0.0371 \\
(0.0068)\end{array}$ \\
\hline 1994 & $\begin{array}{c}0.8144 \\
(0.0055)\end{array}$ & $\begin{array}{c}0.9261 \\
(0.0029)\end{array}$ & $\begin{array}{c}0.7512 \\
(0.0035)\end{array}$ & $\begin{array}{l}-0.1117 \\
(0.0062)\end{array}$ & $\begin{array}{c}0.0632 \\
(0.0065)\end{array}$ \\
\hline 1995 & $\begin{array}{c}0.8240 \\
(0.0056)\end{array}$ & $\begin{array}{c}0.9306 \\
(0.0030)\end{array}$ & $\begin{array}{c}0.7565 \\
(0.0037)\end{array}$ & $\begin{array}{l}-0.1066 \\
(0.0064)\end{array}$ & $\begin{array}{c}0.0675 \\
(0.0067)\end{array}$ \\
\hline 1996 & $\begin{array}{c}0.8369 \\
(0.0054)\end{array}$ & $\begin{array}{c}0.9335 \\
(0.0029)\end{array}$ & $\begin{array}{c}0.7591 \\
(0.0037)\end{array}$ & $\begin{array}{l}-0.0966 \\
(0.0061)\end{array}$ & $\begin{array}{c}0.0778 \\
(0.0065)\end{array}$ \\
\hline 1997 & $\begin{array}{c}0.8546 \\
(0.0052)\end{array}$ & $\begin{array}{c}0.9350 \\
(0.0028)\end{array}$ & $\begin{array}{c}0.7624 \\
(0.0037)\end{array}$ & $\begin{array}{l}-0.0804 \\
(0.0059)\end{array}$ & $\begin{array}{c}0.0922 \\
(0.0064)\end{array}$ \\
\hline 1998 & $\begin{array}{c}0.8734 \\
(0.0049)\end{array}$ & $\begin{array}{c}0.9356 \\
(0.0028) \\
\end{array}$ & $\begin{array}{c}0.7616 \\
(0.0037) \\
\end{array}$ & $\begin{array}{l}-0.0622 \\
(0.0057)\end{array}$ & $\begin{array}{c}0.1118 \\
(0.0062)\end{array}$ \\
\hline
\end{tabular}

Notes: Calculations are from the 1985-1999 March Current Population Surveys. These rates represent the fraction of women in each category that report having worked at all during the year. Women that do not work because of an illness or disability, or because they are going to school, are excluded. All numbers are weighted. Standard errors are in parentheses. 
Table 2

Mean Characteristics of Single Mother and Comparison Households Sample: Women Ages 18-54, CEX

\begin{tabular}{|c|c|c|c|c|c|c|c|c|c|c|}
\hline & \multicolumn{5}{|c|}{ Panel A: 1984 - 1990} & \multicolumn{5}{|c|}{ Panel B: 1991 - 1993} \\
\hline & $\begin{array}{c}\text { Single } \\
\text { Mothers } \\
\text { (1) }\end{array}$ & $\begin{array}{l}\text { Single, no } \\
\text { Children } \\
\text { (2) }\end{array}$ & $\begin{array}{c}\text { Married } \\
\text { Mothers } \\
\text { (3) }\end{array}$ & $\begin{array}{c}\text { Difference } \\
(4)=(1)-(2)\end{array}$ & $\begin{array}{l}\text { Difference } \\
(5)=(1)-(3)\end{array}$ & $\begin{array}{l}\text { Single } \\
\text { Mothers } \\
\text { (1) }\end{array}$ & $\begin{array}{l}\text { Single, no } \\
\text { Children } \\
\text { (2) }\end{array}$ & $\begin{array}{c}\text { Married } \\
\text { Mothers } \\
\text { (3) }\end{array}$ & $\begin{array}{l}\text { Difference } \\
(4)=(1)-(2)\end{array}$ & $\begin{array}{c}\text { Difference } \\
(5)=(1)-(3)\end{array}$ \\
\hline Educational Attainment & & & & & & & & & & \\
\hline High School Dropout & $\begin{array}{c}0.266 \\
(0.012)\end{array}$ & $\begin{array}{c}0.106 \\
(0.007)\end{array}$ & $\begin{array}{c}0.134 \\
(0.004)\end{array}$ & $\begin{array}{c}0.160 \\
(0.014)\end{array}$ & $\begin{array}{c}0.132 \\
(0.008)\end{array}$ & $\begin{array}{c}0.248 \\
(0.017)\end{array}$ & $\begin{array}{c}0.094 \\
(0.011)\end{array}$ & $\begin{array}{c}0.120 \\
(0.006)\end{array}$ & $\begin{array}{c}0.154 \\
(0.020)\end{array}$ & $\begin{array}{c}0.128 \\
(0.013)\end{array}$ \\
\hline High School Graduate & 0.382 & 0.230 & 0.417 & 0.152 & -0.035 & 0.364 & 0.214 & 0.367 & 0.151 & -0.003 \\
\hline & $\begin{array}{c}(0.012) \\
0.240\end{array}$ & $(0.010)$ & $(0.006)$ & $(0.016)$ & $(0.012)$ & $(0.018)$ & $(0.015)$ & $(0.008)$ & $(0.023)$ & $(0.017)$ \\
\hline Some College & $\begin{array}{c}0.240 \\
(0.011)\end{array}$ & $\begin{array}{c}0.335 \\
(0.011)\end{array}$ & $\begin{array}{c}0.307 \\
(0.006)\end{array}$ & $\begin{array}{l}-0.094 \\
(0.016)\end{array}$ & $\begin{array}{l}-0.066 \\
(0.013)\end{array}$ & $\begin{array}{c}0.268 \\
(0.015)\end{array}$ & $\begin{array}{c}0.326 \\
(0.016)\end{array}$ & $\begin{array}{c}0.271 \\
(0.008)\end{array}$ & $\begin{array}{l}-0.058 \\
(0.022)\end{array}$ & $\begin{array}{l}-0.003 \\
(0.018)\end{array}$ \\
\hline Age & $\begin{array}{c}34.68 \\
(0.184)\end{array}$ & $\begin{array}{c}33.22 \\
(0.252)\end{array}$ & $\begin{array}{c}34.93 \\
(0.086)\end{array}$ & $\begin{array}{c}1.460 \\
(0.312)\end{array}$ & $\begin{array}{l}-0.254 \\
(0.204)\end{array}$ & $\begin{array}{c}34.87 \\
(0.323)\end{array}$ & $\begin{array}{c}35.89 \\
(0.382)\end{array}$ & $\begin{array}{c}35.53 \\
(0.116)\end{array}$ & $\begin{array}{l}-1.021 \\
(0.500)\end{array}$ & $\begin{array}{l}-0.661 \\
(0.344)\end{array}$ \\
\hline Employment & $\begin{array}{c}0.704 \\
(0.012)\end{array}$ & $\begin{array}{c}0.924 \\
(0.007)\end{array}$ & $\begin{array}{c}0.704 \\
(0.005)\end{array}$ & $\begin{array}{l}-0.220 \\
(0.014)\end{array}$ & $\begin{array}{c}0.000 \\
(0.013)\end{array}$ & $\begin{array}{c}0.691 \\
(0.018)\end{array}$ & $\begin{array}{c}0.914 \\
(0.010)\end{array}$ & $\begin{array}{c}0.731 \\
(0.008)\end{array}$ & $\begin{array}{l}-0.223 \\
(0.020)\end{array}$ & $\begin{array}{l}-0.040 \\
(0.019)\end{array}$ \\
\hline Family Size & $\begin{array}{l}2.996 \\
(0.030)\end{array}$ & $\begin{array}{c}1.000 \\
(0.000)\end{array}$ & $\begin{array}{c}4.111 \\
(0.012)\end{array}$ & $\begin{array}{c}1.996 \\
(0.030)\end{array}$ & $\begin{array}{l}-1.116 \\
(0.033)\end{array}$ & $\begin{array}{l}2.971 \\
(0.041)\end{array}$ & $\begin{array}{c}1.000 \\
(0.000)\end{array}$ & $\begin{array}{c}4.092 \\
(0.017)\end{array}$ & $\begin{array}{c}1.971 \\
(0.041)\end{array}$ & $\begin{array}{l}-1.121 \\
(0.044)\end{array}$ \\
\hline Race (White=1) & $\begin{array}{c}0.633 \\
(0.012)\end{array}$ & $\begin{array}{c}0.863 \\
(0.008)\end{array}$ & $\begin{array}{c}0.899 \\
(0.003)\end{array}$ & $\begin{array}{l}-0.229 \\
(0.014)\end{array}$ & $\begin{array}{l}-0.266 \\
(0.012)\end{array}$ & $\begin{array}{c}0.659 \\
(0.020)\end{array}$ & $\begin{array}{c}0.848 \\
(0.012)\end{array}$ & $\begin{array}{c}0.891 \\
(0.005)\end{array}$ & $\begin{array}{l}-0.189 \\
(0.023)\end{array}$ & $\begin{array}{l}-0.232 \\
(0.020)\end{array}$ \\
\hline \multirow[t]{3}{*}{$\mathbf{N}$} & 7,014 & 8,641 & 36,833 & & & 3,266 & 3,695 & 15,121 & & \\
\hline & \multicolumn{5}{|c|}{ Panel C: 1994 - 1995} & \multicolumn{5}{|c|}{ Panel D: 1996 - 1998} \\
\hline & $\begin{array}{l}\text { Single } \\
\text { Mothers } \\
\text { (1) }\end{array}$ & $\begin{array}{c}\text { Single, no } \\
\text { Children } \\
\text { (2) }\end{array}$ & $\begin{array}{l}\text { Married } \\
\text { Mothers } \\
\text { (3) }\end{array}$ & $\begin{array}{c}\text { Difference } \\
(4)=(1)-(2)\end{array}$ & $\begin{array}{c}\text { Difference } \\
(5)=(1)-(3)\end{array}$ & $\begin{array}{l}\text { Single } \\
\text { Mothers } \\
\text { (1) }\end{array}$ & $\begin{array}{l}\text { Single, no } \\
\text { Children } \\
\text { (2) }\end{array}$ & $\begin{array}{c}\text { Married } \\
\text { Mothers } \\
\text { (3) }\end{array}$ & $\begin{array}{c}\text { Difference } \\
(4)=(1)-(2)\end{array}$ & $\begin{array}{c}\text { Difference } \\
(5)=(1)-(3)\end{array}$ \\
\hline Educational Attainment & & & & & & & & & & \\
\hline High School Dropout & $\begin{array}{c}0.217 \\
(0.017)\end{array}$ & $\begin{array}{c}0.074 \\
(0.011)\end{array}$ & $\begin{array}{c}0.118 \\
(0.007)\end{array}$ & $\begin{array}{c}0.143 \\
(0.020)\end{array}$ & $\begin{array}{c}0.099 \\
(0.013)\end{array}$ & $\begin{array}{c}0.189 \\
(0.014)\end{array}$ & $\begin{array}{c}0.054 \\
(0.007)\end{array}$ & $\begin{array}{c}0.111 \\
(0.005)\end{array}$ & $\begin{array}{c}0.135 \\
(0.016)\end{array}$ & $\begin{array}{c}0.077 \\
(0.009)\end{array}$ \\
\hline High School Graduate & 0.406 & 0.207 & 0.348 & 0.199 & 0.057 & 0.366 & 0.193 & 0.307 & 0.173 & 0.059 \\
\hline & $(0.020)$ & $(0.017)$ & $(0.010)$ & $(0.027)$ & $(0.020)$ & $(0.016)$ & $(0.013)$ & $(0.009)$ & $(0.021)$ & $(0.015)$ \\
\hline Some College & $\begin{array}{c}0.277 \\
(0.017)\end{array}$ & $\begin{array}{c}0.355 \\
(0.022)\end{array}$ & $\begin{array}{c}0.273 \\
(0.009)\end{array}$ & $\begin{array}{l}-0.078 \\
(0.028)\end{array}$ & $\begin{array}{c}0.005 \\
(0.024)\end{array}$ & $\begin{array}{c}0.317 \\
(0.017)\end{array}$ & $\begin{array}{c}0.387 \\
(0.015)\end{array}$ & $\begin{array}{c}0.295 \\
(0.008)\end{array}$ & $\begin{array}{l}-0.070 \\
(0.023)\end{array}$ & $\begin{array}{c}0.022 \\
(0.017)\end{array}$ \\
\hline Age & $\begin{array}{l}35.09 \\
(0.333)\end{array}$ & $\begin{array}{c}35.80 \\
(0.469)\end{array}$ & $\begin{array}{c}36.02 \\
(0.152)\end{array}$ & $\begin{array}{l}-0.718 \\
(0.575)\end{array}$ & $\begin{array}{l}-0.939 \\
(0.366)\end{array}$ & $\begin{array}{c}35.55 \\
(0.275)\end{array}$ & $\begin{array}{c}35.70 \\
(0.358)\end{array}$ & $\begin{array}{c}36.70 \\
(0.113)\end{array}$ & $\begin{array}{l}-0.149 \\
(0.452)\end{array}$ & $\begin{array}{l}-1.153 \\
(0.297)\end{array}$ \\
\hline Employment & $\begin{array}{c}0.702 \\
(0.018)\end{array}$ & $\begin{array}{c}0.891 \\
(0.015)\end{array}$ & $\begin{array}{c}0.749 \\
(0.009)\end{array}$ & $\begin{array}{l}-0.189 \\
(0.023)\end{array}$ & $\begin{array}{l}-0.048 \\
(0.020)\end{array}$ & $\begin{array}{c}0.765 \\
(0.014)\end{array}$ & $\begin{array}{c}0.865 \\
(0.012)\end{array}$ & $\begin{array}{c}0.749 \\
(0.007)\end{array}$ & $\begin{array}{l}-0.100 \\
(0.018)\end{array}$ & $\begin{array}{c}0.016 \\
(0.016)\end{array}$ \\
\hline Family Size & $\begin{array}{l}2.977 \\
(0.041)\end{array}$ & $\begin{array}{c}1.000 \\
(0.000)\end{array}$ & $\begin{array}{c}4.095 \\
(0.022)\end{array}$ & $\begin{array}{c}1.977 \\
(0.041)\end{array}$ & $\begin{array}{l}-1.118 \\
(0.046)\end{array}$ & $\begin{array}{l}2.990 \\
(0.034)\end{array}$ & $\begin{array}{c}1.000 \\
(0.000)\end{array}$ & $\begin{array}{c}4.094 \\
(0.016)\end{array}$ & $\begin{array}{c}1.990 \\
(0.034)\end{array}$ & $\begin{array}{l}-1.104 \\
(0.038)\end{array}$ \\
\hline Race (White=1) & $\begin{array}{c}0.644 \\
(0.020)\end{array}$ & $\begin{array}{c}0.865 \\
(0.012)\end{array}$ & $\begin{array}{c}0.894 \\
(0.007)\end{array}$ & $\begin{array}{l}-0.220 \\
(0.023)\end{array}$ & $\begin{array}{l}-0.249 \\
(0.013)\end{array}$ & $\begin{array}{c}0.612 \\
(0.019)\end{array}$ & $\begin{array}{c}0.824 \\
(0.012)\end{array}$ & $\begin{array}{c}0.874 \\
(0.006)\end{array}$ & $\begin{array}{l}-0.212 \\
(0.022)\end{array}$ & $\begin{array}{l}-0.262 \\
(0.014)\end{array}$ \\
\hline $\mathbf{N}$ & 2,324 & 2,543 & 10,194 & & & 3,296 & 4,227 & 14,863 & & \\
\hline
\end{tabular}

Notes: The calculations are from the Consumer Expenditure Survey. Observations represent a household-quarter. See text for additional explanations. All numbers are weighted.

Bootstrap standard errors that correct for within household dependence are in parentheses. The omitted education group is college graduate. 
Table 3

Mean Characteristics of Single Mother and Comparison Households

Sample: Women Ages 18-54, PSID

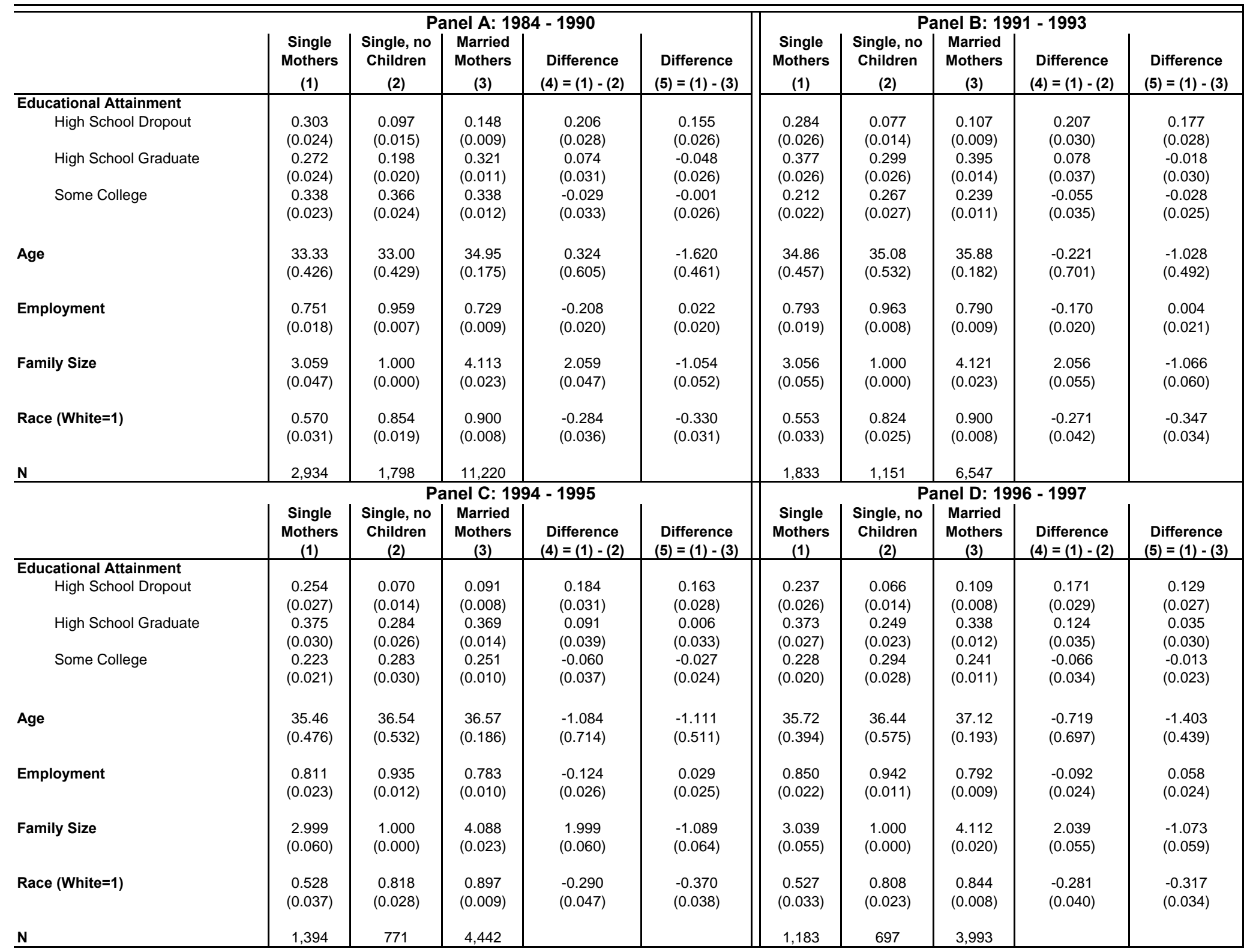

Notes: The calculations are from the Panel Study of Income Dynamics. See text for additional explanations. All numbers are weighted. Bootstrap standard errors that correct for within household dependence are in parentheses. The omitted education group is college graduate. 
Table 4

Mean Characteristics of Single Mother and Comparison Households

Sample: Women Ages 18-54 with a High School Degree or Less, CEX

\begin{tabular}{|c|c|c|c|c|c|c|c|c|c|c|}
\hline & \multicolumn{5}{|c|}{ Panel A: 1984 - 1990} & \multicolumn{5}{|c|}{ Panel B: 1991 - 1993} \\
\hline & $\begin{array}{c}\text { Single } \\
\text { Mothers } \\
\text { (1) }\end{array}$ & $\begin{array}{l}\text { Single, no } \\
\text { Children } \\
(2)\end{array}$ & $\begin{array}{c}\text { Married } \\
\text { Mothers } \\
\text { (3) }\end{array}$ & $\begin{array}{l}\text { Difference } \\
(4)=(1)-(2)\end{array}$ & $\begin{array}{c}\text { Difference } \\
(5)=(1)-(3)\end{array}$ & $\begin{array}{c}\text { Single } \\
\text { Mothers } \\
\text { (1) }\end{array}$ & $\begin{array}{l}\text { Single, no } \\
\text { Children } \\
(2)\end{array}$ & $\begin{array}{c}\text { Married } \\
\text { Mothers } \\
(3)\end{array}$ & $\begin{array}{l}\text { Difference } \\
(4)=(1)-(2)\end{array}$ & $\begin{array}{l}\text { Difference } \\
(5)=(1)-(3)\end{array}$ \\
\hline $\begin{array}{c}\text { Educational Attainment } \\
\text { High School Dropout }\end{array}$ & $\begin{array}{c}0.410 \\
(0.015)\end{array}$ & $\begin{array}{c}0.315 \\
(0.019)\end{array}$ & $\begin{array}{c}0.243 \\
(0.007)\end{array}$ & $\begin{array}{c}0.096 \\
(0.024)\end{array}$ & $\begin{array}{c}0.167 \\
(0.016)\end{array}$ & $\begin{array}{c}0.405 \\
(0.026)\end{array}$ & $\begin{array}{c}0.306 \\
(0.029)\end{array}$ & $\begin{array}{c}0.246 \\
(0.011)\end{array}$ & $\begin{array}{c}0.099 \\
(0.038)\end{array}$ & $\begin{array}{c}0.158 \\
(0.028)\end{array}$ \\
\hline Age & $\begin{array}{c}34.08 \\
(0.251)\end{array}$ & $\begin{array}{l}35.78 \\
(0.476)\end{array}$ & $\begin{array}{c}34.46 \\
(0.114)\end{array}$ & $\begin{array}{l}-1.700 \\
(0.538)\end{array}$ & $\begin{array}{l}-0.376 \\
(0.275)\end{array}$ & $\begin{array}{l}33.632 \\
(0.183)\end{array}$ & $\begin{array}{l}40.020 \\
(0.338)\end{array}$ & $\begin{array}{l}34.725 \\
(0.085)\end{array}$ & $\begin{array}{l}-6.388 \\
(0.385)\end{array}$ & $\begin{array}{l}-1.093 \\
(0.202)\end{array}$ \\
\hline Employment & $\begin{array}{c}0.630 \\
(0.016)\end{array}$ & $\begin{array}{c}0.875 \\
(0.015)\end{array}$ & $\begin{array}{c}0.657 \\
(0.007)\end{array}$ & $\begin{array}{l}-0.245 \\
(0.022)\end{array}$ & $\begin{array}{l}-0.027 \\
(0.018)\end{array}$ & $\begin{array}{c}0.593 \\
(0.011)\end{array}$ & $\begin{array}{c}0.858 \\
(0.010)\end{array}$ & $\begin{array}{c}0.696 \\
(0.005)\end{array}$ & $\begin{array}{l}-0.265 \\
(0.015)\end{array}$ & $\begin{array}{l}-0.102 \\
(0.012)\end{array}$ \\
\hline Family Size & $\begin{array}{c}3.142 \\
(0.037)\end{array}$ & $\begin{array}{c}1.000 \\
(0.000)\end{array}$ & $\begin{array}{c}4.174 \\
(0.018)\end{array}$ & $\begin{array}{c}2.142 \\
(0.037)\end{array}$ & $\begin{array}{l}-1.032 \\
(0.041)\end{array}$ & $\begin{array}{c}3.141 \\
(0.026)\end{array}$ & $\begin{array}{c}1.000 \\
(0.000)\end{array}$ & $\begin{array}{c}4.118 \\
(0.012)\end{array}$ & $\begin{array}{c}2.141 \\
(0.026)\end{array}$ & $\begin{array}{l}-0.977 \\
(0.029)\end{array}$ \\
\hline Race (White=1) & $\begin{array}{c}0.605 \\
(0.015)\end{array}$ & $\begin{array}{c}0.818 \\
(0.016)\end{array}$ & $\begin{array}{c}0.905 \\
(0.005)\end{array}$ & $\begin{array}{l}-0.213 \\
(0.022)\end{array}$ & $\begin{array}{l}-0.300 \\
(0.016)\end{array}$ & $\begin{array}{c}0.606 \\
(0.023)\end{array}$ & $\begin{array}{c}0.799 \\
(0.023)\end{array}$ & $\begin{array}{c}0.885 \\
(0.009)\end{array}$ & $\begin{array}{l}-0.192 \\
(0.033)\end{array}$ & $\begin{array}{l}-0.279 \\
(0.025)\end{array}$ \\
\hline \multirow[t]{3}{*}{$\mathbf{N}$} & 4,529 & 2,840 & 19,949 & & & 1,953 & 1,129 & 7,149 & & \\
\hline & \multicolumn{5}{|c|}{ Panel C: 1994 - 1995} & \multicolumn{5}{|c|}{ Panel D: 1996 - 1998} \\
\hline & $\begin{array}{c}\text { Single } \\
\text { Mothers } \\
\text { (1) }\end{array}$ & $\begin{array}{c}\text { Single, no } \\
\text { Children } \\
(2) \\
\end{array}$ & $\begin{array}{c}\text { Married } \\
\text { Mothers } \\
(3) \\
\end{array}$ & $\begin{array}{c}\text { Difference } \\
(4)=(1)-(2)\end{array}$ & $\begin{array}{c}\text { Difference } \\
(5)=(1)-(3)\end{array}$ & $\begin{array}{c}\text { Single } \\
\text { Mothers } \\
(1) \\
\end{array}$ & $\begin{array}{c}\text { Single, no } \\
\text { Children } \\
(2) \\
\end{array}$ & $\begin{array}{c}\text { Married } \\
\text { Mothers } \\
(3) \\
\end{array}$ & $\begin{array}{c}\text { Difference } \\
(4)=(1)-(2)\end{array}$ & $\begin{array}{c}\text { Difference } \\
(5)=(1)-(3) \\
\end{array}$ \\
\hline $\begin{array}{c}\text { Educational Attainment } \\
\text { High School Dropout }\end{array}$ & $\begin{array}{c}0.348 \\
(0.026)\end{array}$ & $\begin{array}{c}0.263 \\
(0.042)\end{array}$ & $\begin{array}{c}0.253 \\
(0.014)\end{array}$ & $\begin{array}{c}0.085 \\
(0.050)\end{array}$ & $\begin{array}{c}0.095 \\
(0.030)\end{array}$ & $\begin{array}{c}0.340 \\
(0.022)\end{array}$ & $\begin{array}{c}0.218 \\
(0.028)\end{array}$ & $\begin{array}{c}0.266 \\
(0.012)\end{array}$ & $\begin{array}{c}0.122 \\
(0.036)\end{array}$ & $\begin{array}{c}0.074 \\
(0.025)\end{array}$ \\
\hline Age & $\begin{array}{c}33.97 \\
(0.211)\end{array}$ & $\begin{array}{l}39.32 \\
(0.447)\end{array}$ & $\begin{array}{l}35.04 \\
(0.104)\end{array}$ & $\begin{array}{l}-5.36 \\
(0.494)\end{array}$ & $\begin{array}{c}-1.07 \\
(0.236)\end{array}$ & $\begin{array}{c}33.83 \\
(0.182)\end{array}$ & $\begin{array}{l}39.10 \\
(0.346)\end{array}$ & $\begin{array}{l}35.85 \\
(0.091)\end{array}$ & $\begin{array}{l}-5.27 \\
(0.391)\end{array}$ & $\begin{array}{c}-2.02 \\
(0.203)\end{array}$ \\
\hline Employment & $\begin{array}{c}0.646 \\
(0.013)\end{array}$ & $\begin{array}{l}0.773 \\
(0.016)\end{array}$ & $\begin{array}{c}0.692 \\
(0.007)\end{array}$ & $\begin{array}{l}-0.126 \\
(0.021)\end{array}$ & $\begin{array}{l}-0.046 \\
(0.014)\end{array}$ & $\begin{array}{c}0.679 \\
(0.011)\end{array}$ & $\begin{array}{c}0.784 \\
(0.013)\end{array}$ & $\begin{array}{c}0.679 \\
(0.006)\end{array}$ & $\begin{array}{l}-0.105 \\
(0.017)\end{array}$ & $\begin{array}{c}0.000 \\
(0.012)\end{array}$ \\
\hline Family Size & $\begin{array}{c}3.089 \\
(0.028)\end{array}$ & $\begin{array}{c}1.000 \\
(0.000)\end{array}$ & $\begin{array}{l}4.155 \\
(0.016)\end{array}$ & $\begin{array}{c}2.089 \\
(0.028)\end{array}$ & $\begin{array}{l}-1.066 \\
(0.032)\end{array}$ & $\begin{array}{c}3.131 \\
(0.026)\end{array}$ & $\begin{array}{l}1.000 \\
(0.000)\end{array}$ & $\begin{array}{c}4.200 \\
(0.013)\end{array}$ & $\begin{array}{l}2.131 \\
(0.026)\end{array}$ & $\begin{array}{l}-1.069 \\
(0.030)\end{array}$ \\
\hline Race (White=1) & $\begin{array}{c}0.610 \\
(0.026)\end{array}$ & $\begin{array}{c}0.802 \\
(0.032)\end{array}$ & $\begin{array}{c}0.891 \\
(0.009)\end{array}$ & $\begin{array}{l}-0.191 \\
(0.041)\end{array}$ & $\begin{array}{c}-0.281 \\
(0.028)\end{array}$ & $\begin{array}{c}0.548 \\
(0.023)\end{array}$ & $\begin{array}{c}0.768 \\
(0.025)\end{array}$ & $\begin{array}{c}0.863 \\
(0.009)\end{array}$ & $\begin{array}{l}-0.220 \\
(0.034)\end{array}$ & $\begin{array}{l}-0.315 \\
(0.025)\end{array}$ \\
\hline $\mathbf{N}$ & 1,434 & 660 & 4,630 & & & 1,828 & 1,024 & 6,087 & & \\
\hline
\end{tabular}

Notes: See the notes to Table 2. The omitted education group is high school graduate. 
Table 5

Mean Characteristics of Single Mother and Comparison Households

Sample: Women Ages 18-54 with a High School Degree or Less, PSID

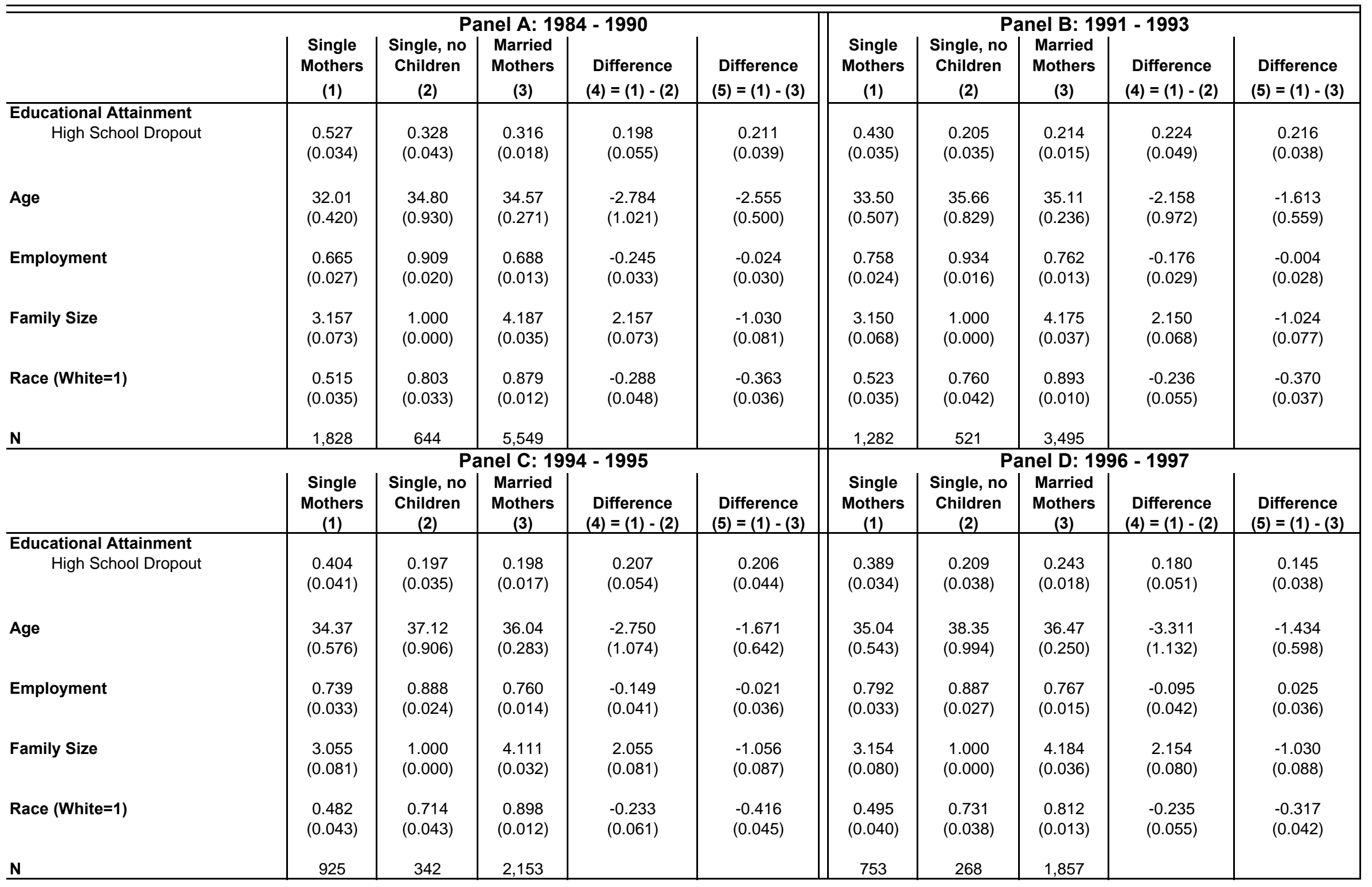

Notes: See the notes to Table 3 . The omitted education group is high school graduate. 
Table 6

Quarterly Consumption by Single Mother and Comparison Households

Sample: Women Ages 18-54, CEX and PSID

\begin{tabular}{|c|c|c|c|c|c|c|c|c|c|c|}
\hline & $\begin{array}{c}\text { Single } \\
\text { Mothers } \\
\text { (1) }\end{array}$ & $\begin{array}{l}\mathrm{P} \\
\text { Single, no } \\
\text { Children } \\
(2)\end{array}$ & $\begin{array}{l}\text { nel A: } 19 \\
\text { Married } \\
\text { Mothers } \\
\text { (3) }\end{array}$ & $\begin{array}{c}4-1990 \\
\text { Ratio } \\
(4)=(1) /(2)\end{array}$ & $\begin{array}{c}\text { Ratio } \\
(5)=(1) /(3)\end{array}$ & $\begin{array}{c}\text { Single } \\
\text { Mothers } \\
\text { (1) }\end{array}$ & $\begin{array}{l}\mathrm{P} \\
\text { Single, no } \\
\text { Children } \\
(2)\end{array}$ & $\begin{array}{l}\text { nel B: } 19 \\
\text { Married } \\
\text { Mothers } \\
\text { (3) }\end{array}$ & $\begin{array}{l}1 \text { - } 1993 \\
\text { Ratio } \\
(4)=(1) /(2)\end{array}$ & $\begin{array}{c}\quad \text { Ratio } \\
(5)=(1) /(3)\end{array}$ \\
\hline $\begin{array}{l}\text { CEX } \\
\text { Total }\end{array}$ & $\begin{array}{c}4,593 \\
(86.19)\end{array}$ & $\begin{array}{c}4,261 \\
(53.18)\end{array}$ & $\begin{array}{c}8,662 \\
(49.32)\end{array}$ & $\begin{array}{c}1.078 \\
(0.024)\end{array}$ & $\begin{array}{c}0.530 \\
(0.010)\end{array}$ & $\begin{array}{c}4,519 \\
(83.16)\end{array}$ & $\begin{array}{c}4,326 \\
(73.84)\end{array}$ & $\begin{array}{c}8,432 \\
(72.14)\end{array}$ & $\begin{array}{c}1.045 \\
(0.026)\end{array}$ & $\begin{array}{c}0.536 \\
(0.011)\end{array}$ \\
\hline Food & $\begin{array}{c}998 \\
(12.64)\end{array}$ & $\begin{array}{c}651 \\
(8.77)\end{array}$ & $\begin{array}{l}1,654 \\
(9.97)\end{array}$ & $\begin{array}{c}1.534 \\
(0.028)\end{array}$ & $\begin{array}{c}0.603 \\
(0.008)\end{array}$ & $\begin{array}{c}991 \\
(16.17)\end{array}$ & $\begin{array}{c}675 \\
(10.32)\end{array}$ & $\begin{array}{c}1,609 \\
(14.75)\end{array}$ & $\begin{array}{c}1.468 \\
(0.033)\end{array}$ & $\begin{array}{c}0.616 \\
(0.012)\end{array}$ \\
\hline Housing & $\begin{array}{l}2,073 \\
(48.40)\end{array}$ & $\begin{array}{c}1,914 \\
(29.54)\end{array}$ & $\begin{array}{c}3,438 \\
(20.73)\end{array}$ & $\begin{array}{c}1.083 \\
(0.030)\end{array}$ & $\begin{array}{c}0.603 \\
(0.015)\end{array}$ & $\begin{array}{c}2,043 \\
(43.86)\end{array}$ & $\begin{array}{c}1,987 \\
(38.34)\end{array}$ & $\begin{array}{c}3,391 \\
(34.13)\end{array}$ & $\begin{array}{c}1.028 \\
(0.030)\end{array}$ & $\begin{array}{c}0.603 \\
(0.014)\end{array}$ \\
\hline Discretionary & $\begin{array}{c}826 \\
(19.43)\end{array}$ & $\begin{array}{c}945 \\
(22.46)\end{array}$ & $\begin{array}{c}1,810 \\
(19.40)\end{array}$ & $\begin{array}{c}0.874 \\
(0.029)\end{array}$ & $\begin{array}{c}0.456 \\
(0.012)\end{array}$ & $\begin{array}{c}767 \\
(26.95)\end{array}$ & $\begin{array}{c}817 \\
(24.13)\end{array}$ & $\begin{array}{c}1,658 \\
(27.54)\end{array}$ & $\begin{array}{c}0.939 \\
(0.043)\end{array}$ & $\begin{array}{c}0.463 \\
(0.018)\end{array}$ \\
\hline Work Expenses & - & - & - & - & - & $\begin{array}{c}230 \\
(48.51)\end{array}$ & $\begin{array}{c}19 \\
(3.83)\end{array}$ & $\begin{array}{c}432 \\
(34.45)\end{array}$ & $\begin{array}{l}11.836 \\
(3.417)\end{array}$ & $\begin{array}{c}0.532 \\
(0.120)\end{array}$ \\
\hline Child Care & - & - & - & - & - & $\begin{array}{c}94 \\
(18.59)\end{array}$ & - & $\begin{array}{c}164 \\
(14.07)\end{array}$ & - & $\begin{array}{c}0.572 \\
(0.124)\end{array}$ \\
\hline $\mathbf{N}$ & 7,014 & 8,641 & 36,833 & & & 3,266 & 3,695 & 15,121 & & \\
\hline \multicolumn{11}{|l|}{ PSID } \\
\hline Food & $\begin{array}{c}1,125 \\
(19.67)\end{array}$ & $\begin{array}{c}737 \\
(21.06)\end{array}$ & $\begin{array}{c}1,826 \\
(20.58)\end{array}$ & $\begin{array}{c}1.526 \\
(0.051)\end{array}$ & $\begin{array}{c}0.616 \\
(0.013)\end{array}$ & $\begin{array}{c}1,135 \\
(24.15)\end{array}$ & $\begin{array}{c}734 \\
(19.91)\end{array}$ & $\begin{array}{c}1,727 \\
(17.97)\end{array}$ & $\begin{array}{c}1.548 \\
(0.053)\end{array}$ & $\begin{array}{c}0.657 \\
(0.016)\end{array}$ \\
\hline $\mathbf{N}$ & 2,934 & 1,798 & 11,220 & & & 1,833 & 1,151 & 6,547 & & \\
\hline & $\begin{array}{c}\text { Single } \\
\text { Mothers } \\
\text { (1) }\end{array}$ & $\begin{array}{l}\text { P } \\
\text { Single, no } \\
\text { Children } \\
(2)\end{array}$ & $\begin{array}{l}\text { nel C: } 19 \\
\text { Married } \\
\text { Mothers } \\
\text { (3) }\end{array}$ & $\begin{array}{c}4-1995 \\
\quad \begin{array}{c}\text { Ratio } \\
(4)=(1) /(2)\end{array} \\
\end{array}$ & $\begin{array}{c}\text { Ratio } \\
(5)=(1) /(3)\end{array}$ & $\begin{array}{c}\text { Single } \\
\text { Mothers } \\
\text { (1) }\end{array}$ & $\begin{array}{l}\mathbf{P} \\
\text { Single, no } \\
\text { Children } \\
(2)\end{array}$ & $\begin{array}{l}\text { nel D: } 19 \\
\text { Married } \\
\text { Mothers } \\
\text { (3) }\end{array}$ & $\begin{array}{l}6-1998 \\
\quad \begin{array}{c}\text { Ratio } \\
(4)=(1) /(2)\end{array} \\
\end{array}$ & $\begin{array}{l}\quad \text { Ratio } \\
\text { (5) }=(1) /(3)\end{array}$ \\
\hline $\begin{array}{l}\text { CEX } \\
\text { Total }\end{array}$ & $\begin{array}{c}4,597 \\
(92.52)\end{array}$ & $\begin{array}{c}4,418 \\
(101.30)\end{array}$ & $\begin{array}{c}8,686 \\
(75.40)\end{array}$ & $\begin{array}{c}1.040 \\
(0.032)\end{array}$ & $\begin{array}{c}0.529 \\
(0.012)\end{array}$ & $\begin{array}{c}4,933 \\
(93.85)\end{array}$ & $\begin{array}{c}4,389 \\
(69.14)\end{array}$ & $\begin{array}{c}8,881 \\
(73.37)\end{array}$ & $\begin{array}{c}1.124 \\
(0.028)\end{array}$ & $\begin{array}{c}0.555 \\
(0.012)\end{array}$ \\
\hline Food & $\begin{array}{l}1,017 \\
(23.68)\end{array}$ & $\begin{array}{c}684 \\
(15.61)\end{array}$ & $\begin{array}{c}1,598 \\
(16.27)\end{array}$ & $\begin{array}{c}1.486 \\
(0.048)\end{array}$ & $\begin{array}{c}0.636 \\
(0.016)\end{array}$ & $\begin{array}{c}1,010 \\
(17.41)\end{array}$ & $\begin{array}{c}683 \\
(13.03)\end{array}$ & $\begin{array}{c}1,616 \\
(12.44)\end{array}$ & $\begin{array}{c}1.479 \\
(0.038)\end{array}$ & $\begin{array}{c}0.625 \\
(0.012)\end{array}$ \\
\hline Housing & $\begin{array}{c}2,103 \\
(42.19)\end{array}$ & $\begin{array}{c}2,057 \\
(40.72)\end{array}$ & $\begin{array}{c}3,599 \\
(38.92)\end{array}$ & $\begin{array}{c}1.023 \\
(0.029)\end{array}$ & $\begin{array}{c}0.584 \\
(0.013)\end{array}$ & $\begin{array}{c}2,302 \\
(44.68)\end{array}$ & $\begin{array}{c}2,121 \\
(36.97)\end{array}$ & $\begin{array}{c}3,699 \\
(31.05)\end{array}$ & $\begin{array}{c}1.085 \\
(0.028)\end{array}$ & $\begin{array}{c}0.622 \\
(0.013)\end{array}$ \\
\hline Discretionary & $\begin{array}{c}765 \\
(25.43)\end{array}$ & $\begin{array}{c}839 \\
(32.91)\end{array}$ & $\begin{array}{c}1,698 \\
(31.19)\end{array}$ & $\begin{array}{c}0.911 \\
(0.047)\end{array}$ & $\begin{array}{c}0.451 \\
(0.017)\end{array}$ & $\begin{array}{c}807 \\
(29.36)\end{array}$ & $\begin{array}{c}796 \\
(22.78)\end{array}$ & $\begin{array}{c}1,665 \\
(22.69)\end{array}$ & $\begin{array}{c}1.014 \\
(0.047)\end{array}$ & $\begin{array}{c}0.485 \\
(0.019)\end{array}$ \\
\hline Work Expenses & $\begin{array}{c}288 \\
(27.35)\end{array}$ & $\begin{array}{c}41 \\
(8.15)\end{array}$ & $\begin{array}{c}471 \\
(19.50)\end{array}$ & $\begin{array}{c}6.954 \\
(1.517)\end{array}$ & $\begin{array}{c}0.612 \\
(0.063)\end{array}$ & $\begin{array}{c}287 \\
(20.18)\end{array}$ & $\begin{array}{c}35 \\
(6.28)\end{array}$ & $\begin{array}{c}456 \\
(17.40)\end{array}$ & $\begin{array}{c}8.188 \\
(1.575)\end{array}$ & $\begin{array}{c}0.629 \\
(0.050)\end{array}$ \\
\hline Child Care & $\begin{array}{c}123 \\
(10.85)\end{array}$ & - & $\begin{array}{c}182 \\
(8.19)\end{array}$ & - & $\begin{array}{c}0.676 \\
(0.067)\end{array}$ & $\begin{array}{c}118 \\
(8.26)\end{array}$ & - & $\begin{array}{c}178 \\
(7.00)\end{array}$ & - & $\begin{array}{c}0.664 \\
(0.053)\end{array}$ \\
\hline $\mathbf{N}$ & 2,324 & 2,543 & 10,194 & & & 3,296 & 4,227 & 14,863 & & \\
\hline PSID & & & & & & & & & & \\
\hline Food & $\begin{array}{c}1,137 \\
(27.33)\end{array}$ & $\begin{array}{c}766 \\
(23.81)\end{array}$ & $\begin{array}{c}1,711 \\
(19.01)\end{array}$ & $\begin{array}{c}1.485 \\
(0.058)\end{array}$ & $\begin{array}{c}0.664 \\
(0.018)\end{array}$ & $\begin{array}{c}1,117 \\
(23.68)\end{array}$ & $\begin{array}{c}743 \\
(23.81)\end{array}$ & $\begin{array}{c}1,738 \\
(22.20)\end{array}$ & $\begin{array}{c}1.503 \\
(0.058)\end{array}$ & $\begin{array}{c}0.643 \\
(0.016)\end{array}$ \\
\hline $\mathbf{N}$ & 1,394 & 771 & 4,442 & & & 1,183 & 697 & 3,993 & & \\
\hline
\end{tabular}

Notes : All consumption figures are expressed in 1995:2 dollars using the Personal Consumption Expenditure index reported by the Bureau of Economic Analysis. The components of consumption needed to determine child care and work expenses were not available before the fourth quarter of 1993 . Thus, child care and work expenses reported in Panel B only include observations from the last quarter of this period. See the notes to Table 2 for additional comments. 
Table 7

Quarterly Consumption by Single Mother and Comparison Households

Sample: Women Ages 18-54 with a High School Degree or Less, CEX and PSID

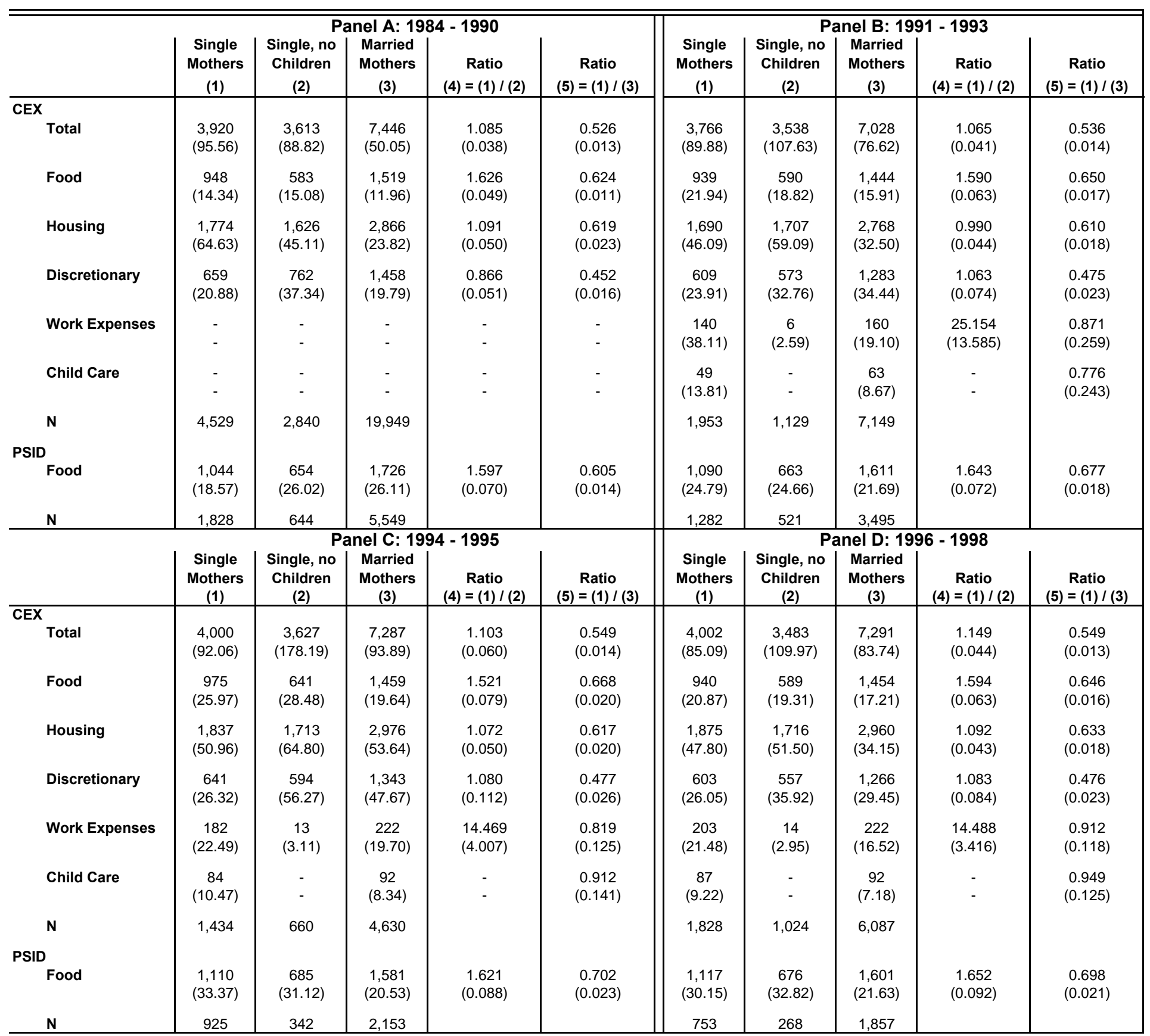

Notes: See the notes to Table 6. 
Table 8

Regression and Quantile Estimates of the Level of Log Consumption for Single Mother Households 1984 - 1998, CEX

\begin{tabular}{|c|c|c|c|c|c|}
\hline & OLS & \multicolumn{4}{|c|}{ Quantile Regressions } \\
\hline & \multirow{2}{*}{$\begin{array}{l}\text { Single Mothers with High } \\
\text { School Degree or Less }\end{array}$} & \multicolumn{2}{|c|}{ All Single Mothers } & \multicolumn{2}{|c|}{$\begin{array}{c}\text { Single Mothers with High Schoo } \\
\text { Degree or Less }\end{array}$} \\
\hline & & 25th Percentile & 15th Percentile & 25th Percentile & 15th Percentile \\
\hline & (1) & $(2)$ & (3) & (4) & (5) \\
\hline $1991-1993$ & $\begin{array}{c}0.0032 \\
(0.0249)\end{array}$ & $\begin{array}{c}0.0137 \\
(0.0257)\end{array}$ & $\begin{array}{c}0.0289 \\
(0.0273)\end{array}$ & $\begin{array}{c}0.0173 \\
(0.0294)\end{array}$ & $\begin{array}{c}0.0363 \\
(0.0283)\end{array}$ \\
\hline 1994-1995 & $\begin{array}{c}0.0640 \\
(0.0285)\end{array}$ & $\begin{array}{c}0.0448 \\
(0.0263)\end{array}$ & $\begin{array}{c}0.0141 \\
(0.0375)\end{array}$ & $\begin{array}{c}0.0915 \\
(0.0390)\end{array}$ & $\begin{array}{c}0.0899 \\
(0.0404)\end{array}$ \\
\hline $1996-1998$ & $\begin{array}{c}0.0838 \\
(0.0259)\end{array}$ & $\begin{array}{c}0.0978 \\
(0.0241)\end{array}$ & $\begin{array}{c}0.1068 \\
(0.0297)\end{array}$ & $\begin{array}{c}0.1241 \\
(0.0298)\end{array}$ & $\begin{array}{c}0.1191 \\
(0.0319)\end{array}$ \\
\hline \multicolumn{6}{|l|}{ P-values from tests of linear restrictions: } \\
\hline$H_{0}: 1994-1995-1984-1990=0$ & 0.0250 & 0.0880 & 0.7070 & 0.0190 & 0.0260 \\
\hline$H_{0}: 1996-1998-1984-1990=0$ & 0.0010 & 0.0000 & 0.0000 & 0.0000 & 0.0000 \\
\hline$H_{0}: 1994-1995-1991-1993=0$ & 0.0445 & 0.3173 & 0.6770 & 0.0554 & 0.1736 \\
\hline$H_{0}: 1996-1998-1991-1993=0$ & 0.0046 & 0.0019 & 0.0123 & 0.0017 & 0.0143 \\
\hline$H_{0}: 1996-1998-1994-1995=0$ & 0.5054 & 0.0751 & 0.0148 & 0.4634 & 0.4795 \\
\hline$H_{0}: 1994-1995-1984-1990<-0.05$ & 0.0001 & 0.0002 & 0.0438 & 0.0002 & 0.0003 \\
\hline$H_{0}: 1996-1998-1984-1990<-0.05$ & 0.0000 & 0.0000 & 0.0000 & 0.0000 & 0.0000 \\
\hline$H_{0}: 1994-1995-1991-1993<-0.05$ & 0.0002 & 0.0046 & 0.1611 & 0.0007 & 0.0043 \\
\hline$H_{0}: 1996-1998-1991-1993<-0.05$ & 0.0000 & 0.0000 & 0.0000 & 0.0000 & 0.0001 \\
\hline$H_{0}: 1996-1998-1994-1995<-0.05$ & 0.0095 & 0.0003 & 0.0001 & 0.0315 & 0.0275 \\
\hline $\mathbf{N}$ & 9,744 & 15,900 & 15,900 & 9,744 & 9,744 \\
\hline
\end{tabular}

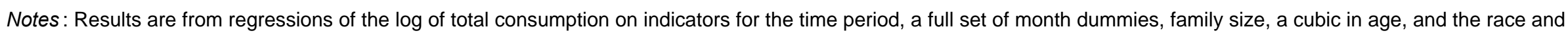

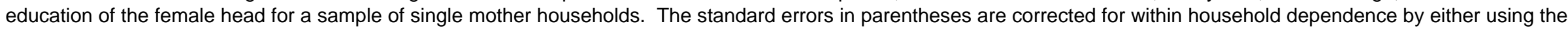
conventional White estimator (OLS) or by bootstrapping (quantile regressions). 
Table 9

Regression and Quantile Estimates of Total Consumption by Single Mother and Comparison Households 1984 - 1998, CEX

\begin{tabular}{|c|c|c|c|c|c|c|c|c|c|c|}
\hline & \multirow{3}{*}{\multicolumn{2}{|c|}{ 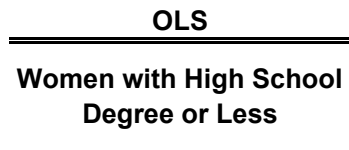 }} & \multicolumn{8}{|c|}{ Quantile Regressions } \\
\hline & & & \multirow{2}{*}{\multicolumn{2}{|c|}{$\begin{array}{c}\text { All Women } \\
\text { 25th Percentile }\end{array}$}} & \multirow{2}{*}{\multicolumn{2}{|c|}{$\begin{array}{c}\begin{array}{c}\text { Women with High School } \\
\text { Degree or Less }\end{array} \\
\text { 25th Percentile }\end{array}$}} & \multirow{2}{*}{\multicolumn{2}{|c|}{$\begin{array}{c}\text { All Women } \\
\text { 15th Percentile }\end{array}$}} & \multirow{2}{*}{\multicolumn{2}{|c|}{$\begin{array}{c}\text { Women with High Schoo } \\
\text { Degree or Less }\end{array}$}} \\
\hline & & & & & & & & & & \\
\hline Single Mother $1984-1990$ & $\begin{array}{c}0.0954 \\
(0.0722)\end{array}$ & $\begin{array}{l}-0.4427 \\
(0.0243)\end{array}$ & $\begin{array}{l}0.0791 \\
(0.0671)\end{array}$ & $\begin{array}{l}-0.4638 \\
(0.0276)\end{array}$ & $\begin{array}{c}0.0982 \\
(0.0939)\end{array}$ & $\begin{array}{l}-0.4587 \\
(0.0339)\end{array}$ & $\begin{array}{c}0.0736 \\
(0.0848)\end{array}$ & $\begin{array}{l}-0.4848 \\
(0.0331)\end{array}$ & $\begin{array}{c}0.1266 \\
(0.1026)\end{array}$ & $\begin{array}{l}-0.4754 \\
(0.0381)\end{array}$ \\
\hline Single Mother*1991-1993 & $\begin{array}{c}0.1333 \\
(0.0736)\end{array}$ & $\begin{array}{l}-0.3960 \\
(0.0288)\end{array}$ & $\begin{array}{l}0.1025 \\
(0.0671)\end{array}$ & $\begin{array}{l}-0.3987 \\
(0.0301)\end{array}$ & $\begin{array}{c}0.1432 \\
(0.0956)\end{array}$ & $\begin{array}{l}-0.3956 \\
(0.0383)\end{array}$ & $\begin{array}{c}0.0962 \\
(0.0850)\end{array}$ & $\begin{array}{l}-0.4113 \\
(0.0375)\end{array}$ & $\begin{array}{c}0.1948 \\
(0.1085)\end{array}$ & $\begin{array}{l}-0.4184 \\
(0.0458)\end{array}$ \\
\hline Single Mother*1994-1995 & $\begin{array}{c}0.1867 \\
(0.0813)\end{array}$ & $\begin{array}{l}-0.3608 \\
(0.0338)\end{array}$ & $\begin{array}{c}0.1118 \\
(0.0705)\end{array}$ & $\begin{array}{l}-0.4011 \\
(0.0355)\end{array}$ & $\begin{array}{c}0.2043 \\
(0.1108)\end{array}$ & $\begin{array}{l}-0.3493 \\
(0.0451)\end{array}$ & $\begin{array}{c}0.0817 \\
(0.0841)\end{array}$ & $\begin{array}{l}-0.4289 \\
(0.0447)\end{array}$ & $\begin{array}{c}0.1963 \\
(0.1085)\end{array}$ & $\begin{array}{l}-0.4001 \\
(0.0535)\end{array}$ \\
\hline Single Mother*1996-1998 & $\begin{array}{c}0.2273 \\
(0.0766)\end{array}$ & $\begin{array}{l}-0.3381 \\
(0.0297)\end{array}$ & $\begin{array}{c}0.1682 \\
(0.0665)\end{array}$ & $\begin{array}{l}-0.3364 \\
(0.0323)\end{array}$ & $\begin{array}{c}0.2436 \\
(0.1065)\end{array}$ & $\begin{array}{l}-0.3078 \\
(0.0371)\end{array}$ & $\begin{array}{c}0.1621 \\
(0.0813)\end{array}$ & $\begin{array}{l}-0.3560 \\
(0.0377)\end{array}$ & $\begin{array}{c}0.2301 \\
(0.1083)\end{array}$ & $\begin{array}{l}-0.3378 \\
(0.0453)\end{array}$ \\
\hline $1991-1993$ & $\begin{array}{l}-0.0322 \\
(0.0367)\end{array}$ & $\begin{array}{l}-0.0455 \\
(0.0111)\end{array}$ & $\begin{array}{l}-0.0066 \\
(0.0246)\end{array}$ & $\begin{array}{l}-0.0467 \\
(0.0090)\end{array}$ & $\begin{array}{l}-0.0140 \\
(0.0447)\end{array}$ & $\begin{array}{l}-0.0345 \\
(0.0135)\end{array}$ & $\begin{array}{c}0.0028 \\
(0.0283)\end{array}$ & $\begin{array}{l}-0.0410 \\
(0.0105)\end{array}$ & $\begin{array}{l}-0.0244 \\
(0.0614)\end{array}$ & $\begin{array}{l}-0.0252 \\
(0.0154)\end{array}$ \\
\hline 1994-1995 & $\begin{array}{l}-0.0269 \\
(0.0445)\end{array}$ & $\begin{array}{l}-0.0219 \\
(0.0126)\end{array}$ & $\begin{array}{l}0.0098 \\
(0.0272)\end{array}$ & $\begin{array}{l}-0.0258 \\
(0.0093)\end{array}$ & $\begin{array}{c}0.0035 \\
(0.0622)\end{array}$ & $\begin{array}{l}-0.0038 \\
(0.0154)\end{array}$ & $\begin{array}{l}0.0198 \\
(0.0290)\end{array}$ & $\begin{array}{l}-0.0200 \\
(0.0115)\end{array}$ & $\begin{array}{l}0.0351 \\
(0.0568)\end{array}$ & $\begin{array}{c}0.0115 \\
(0.0183)\end{array}$ \\
\hline $1996-1998$ & $\begin{array}{l}-0.0491 \\
(0.0372)\end{array}$ & $\begin{array}{l}-0.0281 \\
(0.0119)\end{array}$ & $\begin{array}{l}-0.0036 \\
(0.0261)\end{array}$ & $\begin{array}{l}-0.0380 \\
(0.0096)\end{array}$ & $\begin{array}{l}-0.0149 \\
(0.0479)\end{array}$ & $\begin{array}{l}-0.0301 \\
(0.0131)\end{array}$ & $\begin{array}{l}0.0188 \\
(0.0280)\end{array}$ & $\begin{array}{l}-0.0351 \\
(0.0109)\end{array}$ & $\begin{array}{c}0.0067 \\
(0.0478)\end{array}$ & $\begin{array}{l}-0.0237 \\
(0.0148)\end{array}$ \\
\hline \multicolumn{11}{|l|}{ P-values from tests of linear restrictions: } \\
\hline $\mathrm{H}_{0}: \mathrm{SM}^{*} 1994-1995-\mathrm{SM}^{*} 1984-1990=0$ & 0.0847 & 0.0081 & 0.4455 & 0.0458 & 0.1804 & 0.0130 & 0.8672 & 0.1349 & 0.3417 & 0.0874 \\
\hline $\mathrm{H}_{0}: \mathrm{SM}^{*} 1996-1998-\mathrm{SM}^{*} 1984-1990=0$ & 0.0034 & 0.0002 & 0.0104 & 0.0000 & 0.0124 & 0.0000 & 0.0296 & 0.0000 & 0.0783 & 0.0002 \\
\hline $\mathrm{H}_{0}: \mathrm{SM}^{\star 1} 1994-1995-\mathrm{SM}^{*} 1991-1993=0$ & 0.3459 & 0.2904 & 0.8421 & 0.9466 & 0.4749 & 0.3277 & 0.7723 & 0.6819 & 0.9868 & 0.6897 \\
\hline$H_{0}: S M^{*} 1996-1998-S^{*} 1991-1993=0$ & 0.0660 & 0.0668 & 0.1177 & 0.0387 & 0.1739 & 0.0278 & 0.1675 & 0.1243 & 0.6620 & 0.0584 \\
\hline $\mathrm{H}_{0}: \mathrm{SM}^{*} 1996-1998-\mathrm{SM}^{*} 1994-1995=0$ & 0.4720 & 0.4887 & 0.2104 & 0.0509 & 0.6500 & 0.3491 & 0.1087 & 0.0537 & 0.6388 & 0.1858 \\
\hline $\mathrm{H}_{0}: \mathrm{SM}^{*} 1994-1995-\mathrm{SM}^{*} 1984-1990<-0.05$ & 0.0039 & 0.0000 & 0.0269 & 0.0002 & 0.0244 & 0.0002 & 0.1151 & 0.0023 & 0.0513 & 0.0022 \\
\hline $\mathrm{H}_{0}: \mathrm{SM}^{\star} 1996-1998-\mathrm{SM}^{\star} 1984-1990<-0.05$ & 0.0001 & 0.0000 & 0.0001 & 0.0000 & 0.0004 & 0.0000 & 0.0004 & 0.0000 & 0.0045 & 0.0000 \\
\hline $\mathrm{H}_{0}: \mathrm{SM}^{*} 1994-1995-\mathrm{SM}^{*} 1991-1993<-0.05$ & 0.0341 & 0.0053 & 0.1009 & 0.0972 & 0.0970 & 0.0210 & 0.2396 & 0.2256 & 0.2778 & 0.0676 \\
\hline $\mathrm{H}_{0}: \mathrm{SM}^{*} 1996-1998-\mathrm{SM}^{*} 1991-1993<-0.05$ & 0.0025 & 0.0003 & 0.0030 & 0.0001 & 0.0209 & 0.0003 & 0.0076 & 0.0017 & 0.1453 & 0.0011 \\
\hline $\mathrm{H}_{0}: \mathrm{SM}^{*} 1996-1998-\mathrm{SM}^{*} 1994-1995<-0.05$ & 0.0542 & 0.0134 & 0.0091 & 0.0003 & 0.1513 & 0.0195 & 0.0047 & 0.0006 & 0.1224 & 0.0086 \\
\hline$\underline{N}$ & 15,397 & 47,559 & 35,006 & 92,911 & 15,397 & 47,559 & 35,006 & 92,911 & 15,397 & 47,559 \\
\hline
\end{tabular}

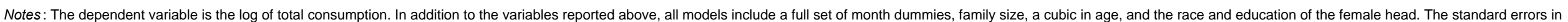
parentheses are corrected for within household dependence by either using the conventional White estimator (OLS) or by bootstrapping (quantile regressions). 
Table 10

Regression and Quantile Estimates of Food Consumption by Single Mother and Comparison Households 1984 - 1998, CEX

\begin{tabular}{|c|c|c|c|c|c|c|c|c|c|c|}
\hline & & & \multicolumn{8}{|c|}{ Quantile Regressions } \\
\hline & \multirow{2}{*}{\multicolumn{2}{|c|}{$\begin{array}{c}\text { Women with High School } \\
\text { Degree or Less }\end{array}$}} & \multirow{2}{*}{\multicolumn{2}{|c|}{$\begin{array}{c}\text { All Women } \\
\text { 25th Percentile }\end{array}$}} & \multirow{2}{*}{\multicolumn{2}{|c|}{$\begin{array}{c}\begin{array}{c}\text { Women with High School } \\
\text { Degree or Less }\end{array} \\
\text { 25th Percentile }\end{array}$}} & \multirow{2}{*}{\multicolumn{2}{|c|}{$\begin{array}{c}\text { All Women } \\
\text { 15th Percentile }\end{array}$}} & \multirow{2}{*}{\multicolumn{2}{|c|}{$\begin{array}{c}\begin{array}{c}\text { Women with High Schoo } \\
\text { Degree or Less }\end{array} \\
\text { 15th Percentile }\end{array}$}} \\
\hline & & & & & & & & & & \\
\hline & $\begin{array}{l}\text { Single } \\
\text { (1) }\end{array}$ & $\begin{array}{c}\text { Mothers } \\
(2)\end{array}$ & $\begin{array}{c}\text { Single } \\
(3)\end{array}$ & $\begin{array}{c}\text { Mothers } \\
(4)\end{array}$ & $\begin{array}{c}\text { Single } \\
(5)\end{array}$ & $\begin{array}{c}\text { Mothers } \\
(6)\end{array}$ & $\begin{array}{c}\text { Single } \\
(7)\end{array}$ & $\begin{array}{c}\begin{array}{c}\text { Mothers } \\
(8)\end{array} \\
\end{array}$ & $\begin{array}{c}\text { Single } \\
(9)\end{array}$ & $\begin{array}{c}\text { Mothers } \\
(10)\end{array}$ \\
\hline Single Mother*1984-1990 & $\begin{array}{c}0.2013 \\
(0.0769)\end{array}$ & $\begin{array}{l}-0.2802 \\
(0.0246)\end{array}$ & $\begin{array}{c}0.2643 \\
(0.0785)\end{array}$ & $\begin{array}{l}-0.2852 \\
(0.0246)\end{array}$ & $\begin{array}{c}0.3232 \\
(0.1068)\end{array}$ & $\begin{array}{l}-0.2427 \\
(0.0317)\end{array}$ & $\begin{array}{c}0.2164 \\
(0.0903)\end{array}$ & $\begin{array}{l}-0.3135 \\
(0.0302)\end{array}$ & $\begin{array}{c}0.2895 \\
(0.1134)\end{array}$ & $\begin{array}{l}-0.2670 \\
(0.0369)\end{array}$ \\
\hline Single Mother*1991-1993 & $\begin{array}{c}0.2048 \\
(0.0829)\end{array}$ & $\begin{array}{l}-0.2330 \\
(0.0292)\end{array}$ & $\begin{array}{c}0.2127 \\
(0.0858)\end{array}$ & $\begin{array}{l}-0.2514 \\
(0.0304)\end{array}$ & $\begin{array}{c}0.2489 \\
(0.1193)\end{array}$ & $\begin{array}{l}-0.2250 \\
(0.0391)\end{array}$ & $\begin{array}{c}0.1639 \\
(0.0946)\end{array}$ & $\begin{array}{l}-0.2878 \\
(0.0302)\end{array}$ & $\begin{array}{c}0.1969 \\
(0.1202)\end{array}$ & $\begin{array}{c}-0.2601 \\
(0.0385)\end{array}$ \\
\hline Single Mother*1994-1995 & $\begin{array}{c}0.1468 \\
(0.0861)\end{array}$ & $\begin{array}{c}-0.1898 \\
(0.0327)\end{array}$ & $\begin{array}{c}0.2371 \\
(0.0814)\end{array}$ & $\begin{array}{l}-0.2141 \\
(0.0279)\end{array}$ & $\begin{array}{c}0.2201 \\
(0.1121)\end{array}$ & $\begin{array}{l}-0.1907 \\
(0.0343)\end{array}$ & $\begin{array}{c}0.1521 \\
(0.0985)\end{array}$ & $\begin{array}{c}-0.2764 \\
(0.0392)\end{array}$ & $\begin{array}{c}0.1369 \\
(0.1299)\end{array}$ & $\begin{array}{l}-0.2346 \\
(0.0456)\end{array}$ \\
\hline Single Mother*1996-1998 & $\begin{array}{c}0.1907 \\
(0.0814)\end{array}$ & $\begin{array}{l}-0.2073 \\
(0.0307)\end{array}$ & $\begin{array}{c}0.2064 \\
(0.0796)\end{array}$ & $\begin{array}{l}-0.2401 \\
(0.0283)\end{array}$ & $\begin{array}{c}0.2831 \\
(0.1135)\end{array}$ & $\begin{array}{l}-0.1987 \\
(0.0365)\end{array}$ & $\begin{array}{c}0.1500 \\
(0.0888)\end{array}$ & $\begin{array}{l}-0.2601 \\
(0.0308)\end{array}$ & $\begin{array}{c}0.2778 \\
(0.1267)\end{array}$ & $\begin{array}{l}-0.2000 \\
(0.0401)\end{array}$ \\
\hline $1991-1993$ & $\begin{array}{c}0.0053 \\
(0.0413)\end{array}$ & $\begin{array}{l}-0.0354 \\
(0.0118)\end{array}$ & $\begin{array}{c}0.0453 \\
(0.0249)\end{array}$ & $\begin{array}{l}-0.0509 \\
(0.0098)\end{array}$ & $\begin{array}{c}0.0637 \\
(0.0438)\end{array}$ & $\begin{array}{l}-0.0321 \\
(0.0152)\end{array}$ & $\begin{array}{c}0.0509 \\
(0.0278)\end{array}$ & $\begin{array}{l}-0.0391 \\
(0.0115)\end{array}$ & $\begin{array}{c}0.0838 \\
(0.0429)\end{array}$ & $\begin{array}{l}-0.0218 \\
(0.0201)\end{array}$ \\
\hline 1994-1995 & $\begin{array}{c}0.1121 \\
(0.0433)\end{array}$ & $\begin{array}{l}-0.0359 \\
(0.0126)\end{array}$ & $\begin{array}{c}0.0355 \\
(0.0278)\end{array}$ & $\begin{array}{l}-0.0640 \\
(0.0103)\end{array}$ & $\begin{array}{c}0.1235 \\
(0.0543)\end{array}$ & $\begin{array}{l}-0.0378 \\
(0.0157)\end{array}$ & $\begin{array}{c}0.0590 \\
(0.0274)\end{array}$ & $\begin{array}{l}-0.0505 \\
(0.0126)\end{array}$ & $\begin{array}{c}0.1772 \\
(0.0538)\end{array}$ & $\begin{array}{l}-0.0144 \\
(0.0188)\end{array}$ \\
\hline 1996-1998 & $\begin{array}{c}0.0261 \\
(0.0385)\end{array}$ & $\begin{array}{l}-0.0559 \\
(0.0121)\end{array}$ & $\begin{array}{c}0.0478 \\
(0.0240)\end{array}$ & $\begin{array}{l}-0.0651 \\
(0.0094)\end{array}$ & $\begin{array}{c}0.0437 \\
(0.0497)\end{array}$ & $\begin{array}{l}-0.0586 \\
(0.0149)\end{array}$ & $\begin{array}{l}0.0691 \\
(0.0268)\end{array}$ & $\begin{array}{l}-0.0568 \\
(0.0101)\end{array}$ & $\begin{array}{c}0.0436 \\
(0.0633)\end{array}$ & $\begin{array}{l}-0.0502 \\
(0.0166)\end{array}$ \\
\hline \multicolumn{11}{|l|}{ P-values from tests of linear restrictions: } \\
\hline$H_{0}: S M^{*} 1994-1995-S^{*} \times 1984-1990=0$ & 0.2880 & 0.0036 & 0.4351 & 0.0030 & 0.0892 & 0.1481 & 0.1330 & 0.2673 & 0.0143 & 0.4567 \\
\hline$H_{0}: S^{*} 1996-1998-S^{*} 1984-1990=0$ & 0.8187 & 0.0098 & 0.0669 & 0.0605 & 0.4806 & 0.1827 & 0.0810 & 0.0450 & 0.8773 & 0.0924 \\
\hline$H_{0}: S M^{*} 1994-1995-S^{*} 1991-1993=0$ & 0.3028 & 0.2020 & 0.5446 & 0.2246 & 0.7047 & 0.4137 & 0.7921 & 0.7570 & 0.3815 & 0.5829 \\
\hline$H_{0}: S M^{*} 1996-1998-S^{\star} 1991-1993=0$ & 0.7946 & 0.4246 & 0.8677 & 0.7055 & 0.6485 & 0.5127 & 0.7349 & 0.2975 & 0.2761 & 0.1624 \\
\hline $\mathrm{H}_{0}: \mathrm{SM}^{\star 1} 1996-1998-\mathrm{SM}^{\star 1} 1994-1995=0$ & 0.4310 & 0.6109 & 0.4339 & 0.3714 & 0.3977 & 0.8381 & 0.9644 & 0.6557 & 0.1009 & 0.4741 \\
\hline$H_{0}: S^{*} 1994-1995-S^{\star} 1984-1990<-0.05$ & 0.4651 & 0.0000 & 0.2571 & 0.0000 & 0.1906 & 0.0023 & 0.3696 & 0.0046 & 0.0498 & 0.0290 \\
\hline$H_{0}: S^{*} 1996-1998-S^{*} 1984-1990<-0.05$ & 0.1955 & 0.0000 & 0.4014 & 0.0001 & 0.4310 & 0.0022 & 0.3334 & 0.0001 & 0.3063 & 0.0017 \\
\hline$H_{0}: S^{*} 1994-1995-S^{*} 1991-1993<-0.05$ & 0.4430 & 0.0030 & 0.0322 & 0.0023 & 0.3898 & 0.0222 & 0.1959 & 0.0471 & 0.4419 & 0.0520 \\
\hline$H_{0}: S M^{*} 1996-1998-S^{*} 1991-1993<-0.05$ & 0.2542 & 0.0093 & 0.1244 & 0.0202 & 0.1312 & 0.0287 & 0.1897 & 0.0017 & 0.0390 & 0.0053 \\
\hline$H_{0}: S M^{\star} 1996-1998-S^{\star} 1994-1995<-0.05$ & 0.0462 & 0.1721 & 0.3107 & 0.2052 & 0.0647 & 0.1407 & 0.1591 & 0.0347 & 0.0131 & 0.0401 \\
\hline $\mathbf{N}$ & 15,397 & 47,559 & 35,006 & 92,911 & 15,397 & 47,559 & 35,006 & 92,911 & 15,397 & 47,559 \\
\hline
\end{tabular}

Notes: The dependent variable is the log of food consumption. See Table 9 for additional notes. 
Table 11

Regression and Quantile Estimates of Food Consumption by Single Mother and Comparison Households 1984 - 1997, PSID

\begin{tabular}{|c|c|c|c|c|c|c|c|c|c|c|}
\hline & \multicolumn{2}{|c|}{ OLS } & \multicolumn{8}{|c|}{ Quantile Regressions } \\
\hline & \multirow{2}{*}{\multicolumn{2}{|c|}{$\begin{array}{l}\text { Women with High School } \\
\text { Degree or Less }\end{array}$}} & \multirow{2}{*}{\multicolumn{2}{|c|}{$\begin{array}{c}\text { All Women } \\
\text { 25th Percentile }\end{array}$}} & \multirow{2}{*}{\multicolumn{2}{|c|}{$\begin{array}{c}\begin{array}{c}\text { Women with High School } \\
\text { Degree or Less }\end{array} \\
\text { 25th Percentile }\end{array}$}} & \multirow{2}{*}{\multicolumn{2}{|c|}{$\begin{array}{c}\text { All Women } \\
\text { 15th Percentile }\end{array}$}} & \multirow{2}{*}{\multicolumn{2}{|c|}{$\begin{array}{c}\begin{array}{c}\text { Women with High School } \\
\text { Degree or Less }\end{array} \\
\text { 15th Percentile }\end{array}$}} \\
\hline & & & & & & & & & & \\
\hline Single Mother ${ }^{*} 1984-1990$ & $\begin{array}{c}0.3869 \\
(0.0909)\end{array}$ & $\begin{array}{l}-0.2890 \\
(0.0295)\end{array}$ & $\begin{array}{c}0.3970 \\
(0.0999)\end{array}$ & $\begin{array}{l}-0.3468 \\
(0.0320)\end{array}$ & $\begin{array}{c}0.3982 \\
(0.1053)\end{array}$ & $\begin{array}{l}-0.3391 \\
(0.0424)\end{array}$ & $\begin{array}{c}0.5255 \\
(0.1112)\end{array}$ & $\begin{array}{l}-0.3469 \\
(0.0366)\end{array}$ & $\begin{array}{c}0.5189 \\
(0.1555)\end{array}$ & $\begin{array}{l}-0.3456 \\
(0.0451)\end{array}$ \\
\hline Single Mother*1991-1993 & $\begin{array}{c}0.3957 \\
(0.0873)\end{array}$ & $\begin{array}{l}-0.1974 \\
(0.0314)\end{array}$ & $\begin{array}{c}0.3604 \\
(0.1013)\end{array}$ & $\begin{array}{l}-0.2529 \\
(0.0320)\end{array}$ & $\begin{array}{c}0.4017 \\
(0.1085)\end{array}$ & $\begin{array}{l}-0.2248 \\
(0.0423)\end{array}$ & $\begin{array}{c}0.4816 \\
(0.1171)\end{array}$ & $\begin{array}{l}-0.3026 \\
(0.0439)\end{array}$ & $\begin{array}{c}0.5145 \\
(0.1595)\end{array}$ & $\begin{array}{l}-0.2953 \\
(0.0533)\end{array}$ \\
\hline Single Mother¹994-1995 & $\begin{array}{c}0.3869 \\
(0.0996)\end{array}$ & $\begin{array}{l}-0.1680 \\
(0.0374)\end{array}$ & $\begin{array}{c}0.3537 \\
(0.1056)\end{array}$ & $\begin{array}{l}-0.2948 \\
(0.0383)\end{array}$ & $\begin{array}{c}0.3317 \\
(0.1172)\end{array}$ & $\begin{array}{l}-0.2455 \\
(0.0470)\end{array}$ & $\begin{array}{c}0.4394 \\
(0.1270)\end{array}$ & $\begin{array}{l}-0.3025 \\
(0.0503)\end{array}$ & $\begin{array}{c}0.4669 \\
(0.1665)\end{array}$ & $\begin{array}{l}-0.2738 \\
(0.0692)\end{array}$ \\
\hline Single Mother¹996-1997 & $\begin{array}{c}0.4399 \\
(0.1018)\end{array}$ & $\begin{array}{l}-0.1677 \\
(0.0321)\end{array}$ & $\begin{array}{c}0.4426 \\
(0.1160)\end{array}$ & $\begin{array}{l}-0.2411 \\
(0.0337)\end{array}$ & $\begin{array}{c}0.5156 \\
(0.1323)\end{array}$ & $\begin{array}{l}-0.1893 \\
(0.0426)\end{array}$ & $\begin{array}{c}0.5942 \\
(0.1185)\end{array}$ & $\begin{array}{l}-0.2329 \\
(0.0475)\end{array}$ & $\begin{array}{c}0.6163 \\
(0.1578)\end{array}$ & $\begin{array}{l}-0.1780 \\
(0.0618)\end{array}$ \\
\hline 1991-1993 & $\begin{array}{c}0.0280 \\
(0.0514)\end{array}$ & $\begin{array}{l}-0.0641 \\
(0.0119)\end{array}$ & $\begin{array}{c}0.0693 \\
(0.0339)\end{array}$ & $\begin{array}{l}-0.0624 \\
(0.0105)\end{array}$ & $\begin{array}{c}0.0517 \\
(0.0612)\end{array}$ & $\begin{array}{l}-0.0548 \\
(0.0149)\end{array}$ & $\begin{array}{c}0.0490 \\
(0.0455)\end{array}$ & $\begin{array}{l}-0.0449 \\
(0.0130)\end{array}$ & $\begin{array}{c}0.0281 \\
(0.0895)\end{array}$ & $\begin{array}{l}-0.0470 \\
(0.0179)\end{array}$ \\
\hline 1994-1995 & $\begin{array}{c}0.0383 \\
(0.0611)\end{array}$ & $\begin{array}{l}-0.0939 \\
(0.0149)\end{array}$ & $\begin{array}{c}0.0261 \\
(0.0423)\end{array}$ & $\begin{array}{l}-0.0770 \\
(0.0136)\end{array}$ & $\begin{array}{c}0.0840 \\
(0.0723)\end{array}$ & $\begin{array}{l}-0.0762 \\
(0.0183)\end{array}$ & $\begin{array}{c}0.0541 \\
(0.0528)\end{array}$ & $\begin{array}{l}-0.0735 \\
(0.0149)\end{array}$ & $\begin{array}{c}0.0577 \\
(0.0950)\end{array}$ & $\begin{array}{l}-0.0734 \\
(0.0230)\end{array}$ \\
\hline 1996-1997 & $\begin{array}{c}0.0060 \\
(0.0693)\end{array}$ & $\begin{array}{l}-0.0771 \\
(0.0155)\end{array}$ & $\begin{array}{l}-0.0306 \\
(0.0632)\end{array}$ & $\begin{array}{l}-0.0768 \\
(0.0148)\end{array}$ & $\begin{array}{l}-0.0351 \\
(0.0874)\end{array}$ & $\begin{array}{l}-0.0818 \\
(0.0223)\end{array}$ & $\begin{array}{l}-0.0385 \\
(0.0518)\end{array}$ & $\begin{array}{l}-0.0844 \\
(0.0146)\end{array}$ & $\begin{array}{l}-0.0125 \\
(0.0845)\end{array}$ & $\begin{array}{l}-0.0809 \\
(0.0239)\end{array}$ \\
\hline $\mathrm{H}_{0}: \mathrm{SM}^{\star} 1994-1995-\mathrm{SM}^{\star} 1984-1990=0$ & 0.9995 & 0.0016 & 0.4146 & 0.1787 & 0.3759 & 0.0265 & 0.2088 & 0.3617 & 0.6192 & 0.2596 \\
\hline $\mathrm{H}_{0}: \mathrm{SM}^{\star} 1996-1997-\mathrm{SM}^{\star} 1984-1990=0$ & 0.4858 & 0.0002 & 0.5038 & 0.0006 & 0.2047 & 0.0002 & 0.2576 & 0.0125 & 0.3242 & 0.0028 \\
\hline $\mathrm{H}_{0}: \mathrm{SM}^{\star} 1994-1995-\mathrm{SM}^{\star} 1991-1993=0$ & 0.8804 & 0.3442 & 0.8852 & 0.2092 & 0.3433 & 0.5827 & 0.5343 & 0.9987 & 0.6604 & 0.7015 \\
\hline $\mathrm{H}_{0}: \mathrm{SM}^{\star} 1996-1997-\mathrm{SM}^{\star} 1991-1993=0$ & 0.5143 & 0.3378 & 0.2332 & 0.7003 & 0.2259 & 0.3449 & 0.1026 & 0.1171 & 0.3520 & 0.0243 \\
\hline $\mathrm{H}_{0}: \mathrm{SM}^{\star} 1996-1997-\mathrm{SM}^{\star} 1994-1995=0$ & 0.3848 & 0.9912 & 0.1788 & 0.0905 & 0.0393 & 0.1397 & 0.0089 & 0.0845 & 0.1248 & 0.1216 \\
\hline $\mathrm{H}_{0}: \mathrm{SM}^{*} 1994-1995-\mathrm{SM}^{*} 1984-1990<-0.05$ & 0.2313 & 0.0000 & 0.4494 & 0.0042 & 0.4131 & 0.0004 & 0.2990 & 0.0262 & 0.4925 & 0.0279 \\
\hline $\mathrm{H}_{0}: \mathrm{SM}^{*} 1996-1997-\mathrm{SM}^{*} 1984-1990<-0.05$ & 0.0880 & 0.0000 & 0.0807 & 0.0000 & 0.0353 & 0.0000 & 0.0252 & 0.0002 & 0.0678 & 0.0001 \\
\hline $\mathrm{H}_{0}: \mathrm{SM}^{*} 1994-1995-\mathrm{SM}^{*} 1991-1993<-0.05$ & 0.2404 & 0.0054 & 0.1754 & 0.4046 & 0.3931 & 0.2184 & 0.4549 & 0.1271 & 0.4908 & 0.1012 \\
\hline $\mathrm{H}_{0}: \mathrm{SM}^{\star} 1996-1997-\mathrm{SM}^{\star} 1991-1993<-0.05$ & 0.0825 & 0.0052 & 0.0276 & 0.0223 & 0.0407 & 0.0115 & 0.0092 & 0.0036 & 0.0826 & 0.0007 \\
\hline $\mathrm{H}_{0}: \mathrm{SM}^{\star} 1996-1997-\mathrm{SM}^{\star} 1994-1995<-0.05$ & 0.0458 & 0.0557 & 0.0179 & 0.0006 & 0.0044 & 0.0027 & 0.0003 & 0.0015 & 0.0203 & 0.0093 \\
\hline $\mathbf{N}$ & 6,550 & 17,830 & 11,748 & 33,534 & 6,550 & 17,830 & 11,748 & 33,534 & 6,550 & 17,830 \\
\hline
\end{tabular}

Notes: The dependent variable is the log of food consumption. See Table 9 for additional notes. 